\title{
Transboundary aquifer mapping and management in Africa: a harmonised approach
}

\author{
Yvan Altchenko \& Karen G. Villholth
}

\section{Introduction}

According to the United Nations International Law Commission's (UNILC) Draft Articles on the Law of Transboundary Aquifers, a transboundary aquifer or a transboundary aquifer system (TBA) is defined as "an aquifer or aquifer system, parts of which are situated in different States" (Article 2c, Stephan 2009). While in principle the term 'transboundary' also refers to local jurisdictional boundaries (of e.g. a community, municipality, province, or region), or to river catchment delineation, the UNILC definition is adhered to here. While not spelled out in the short definition of a TBA, in practical identification and verification of a TBA, the spatial delimitation, hydrogeological similarity, recharge and discharge mechanisms and zones, and significant hydraulic connectivity between the national compartments of the TBA are important and should be established and agreed upon between aquifer-sharing states. The UNILC definition of TBAs does not imply that groundwater resources in border regions outside of TBAs do not exist or manifest similar properties as TBAs. However, the extent and significance of such resources are considered of limited transboundary importance or their transboundary extent have not been identified or acknowledged.

This report focuses on the internationally shared aquifers in Africa. While progress in understanding the importance and extent of these water resources and incipient management frameworks are evident from many reports, relatively little attention has been accorded these resources in the scientific literature. TBAs have been highlighted only since the beginning of the century, initially by the United Nations Educational, Scientific and Cultural Organization (UNESCO) and specifically with the launch in 2000 of the International Shared Aquifer Resources Management Project (ISARM) by UNESCO's Intergovernmental Scientific Cooperative Programme in Hydrology and Water Resources (UNESCO-IHP; Puri and Aureli 2005; UNESCO 2010, 2008, 2004).

Prior to 2000, limited knowledge of TBAs was available, and this certainly was not commensurate with the level of knowledge and management tools and approaches bestowed internationally shared river systems. Hence, an immediate need was to identify, delineate, and map the TBAs at various scales, from local, to regional, to global. The first results of TBA mapping in Africa appeared in 2004 when ISARM 
published the first Africa-wide TBA map after the International Workshop on 'Managing Shared Aquifer Resources in Africa', held in Tripoli, Libya, in June 2002 (UNESCO 2004). Since then, several updated world maps of TBAs have been published, e.g. by the World-wide Hydrogeological Mapping and Assessment Programme (WHYMAP 2006) and the International Groundwater Resources Assessment Centre (IGRAC 2009, 2012a). Each evolution of maps comes with an increase in the number of aquifers identified and a progressively better delineation of the TBAs. Presently, more than 450 TBAs have been identified globally (IGRAC 2012a). This is far more than the number of international river basins at 263 (Cooley et al. 2009). While recognizing the mapping exercise as an ongoing and iterative process, the various available maps lend themselves to confusion and inconsistencies (IGRAC 2012), and there is a need to coordinate and harmonise the present approaches. This is presently underway as IGRAC is currently the principal institution involved in global-level mapping of TBAs (N. Kukuric, IGRAC, personal communication, 2012). This report intends to support this process specifically for the African continent.

Focus on TBAs comes from the recognition of increasing stress on available water resources. Groundwater resources are already heavily relied on in Africa, with an estimated $75 \%$ of the African population dependent on groundwater for basic water supply (UNECA et al. 2000). However, with population increase, climate change and need to combat growing food insecurity, demands for groundwater are set to increase in the future (MacDonald et al. 2012; Clifton et al. 2010). Transboundary groundwater resources in Africa represent and provide resources that at present are not sufficiently explored and utilised or they represent sources that are generally developed indiscriminately and commonly unilaterally (Scheumann and Herrfahrdt-Pähle 2008) with potential adverse impacts on the resources and international relations. Hence, cross-boundary knowledge development, coordination, cooperation and management is necessary to minimise conflict risk and environmental degradation and to expand shared benefits. Conflicts can occur because of groundwater-quality issues, reduced groundwater availability and/or socio-economic issues (e.g. inequity in user access across borders leading to human unrest or migration during drought). Unilateral uses, non-acceded monopole use by few users on one side of the border or adverse transboundary impact on groundwater resources or groundwater-dependent eco-systems from land-use changes is the consequence of failed TBA management. A cautionary example, while outside the region, of this is the Judean and Samarian aquifer systems shared by Israel and the Palestinian Territories. Israel uses $82 \%$ of the abstracted groundwater due to its high agricultural and urban development, while the Palestinians claim the right to a larger share because they suffer from low water availability per capita as well as poor water quality (Eckstein and Eckstein 2003a). Similar, but less extreme examples can be found in Africa, e.g. in the case of the Pomfret-Vergelegen dolomite aquifer (or Khakhe/ Bray dolomite aquifer) between South Africa and Botswana (AFS7 in Fig. 1 and Appendix) (Cobbing et al. 2008; Turton et al. 2006), the Limpopo River alluvial aquifer between South Africa, Zimbabwe and Mozambique (AFS 9) (Owen 2012; Cobbing et al. 2008), and the aquifer systems of the Lake Chad basin (AFWC14), shared by Chad, Cameroon, Niger, Nigeria, the Central African Republic, Sudan, Algeria, and Libya (Scheumann and Alker 2009).

As a significant proportion of Africa's water resources are contained in large international water bodies such as rivers, lakes and aquifers, the sensible management and sharing of these resources and their benefits are an issue of international importance, in terms of water security as well as for the longterm peaceful and equitable development of the continent. International river and lake basin organisations (R/LBOs) and associated international agreements on joint management of surface-water bodies have been established since the 1960s, initially in western Sub-Saharan Africa and later panAfrica, with great financial and technical support from the international community (NEPAD et al. 2011; AMCOW and ANBO 2007). However, only recently has effort been put into defining the most appropriate institutional locus for TBA management in Africa as these underground resources generally do not coincide geographically with the extent of either lake or river basins.

Against this backdrop, this study provides an integrated review of the status and progress of TBA mapping and management in Africa, thereby filling a significant gap in the international scientific literature. Firstly, the report reviews and contributes to the efforts on creating an Africa-wide TBA map. This includes identifying additional TBAs not previously mapped, superimposing for the first time the map of TBAs on the R/LBs, proposing a harmonised nomenclature, and making an updated inventory on key TBA data. Secondly, the report discusses strategic legal and institutional frameworks applicable to TBA management and associated requirements to further progress effective TBA management in Africa. The overall objective of the report is to contribute to harmonised and integrated approaches to mapping and management of TBAs on the continent.

\section{Current status of the TBA identification and mapping efforts in Africa}

In 2004, ISARM published the first Africa-wide TBA map presenting 38 TBAs delineated by ellipses (UNESCO 2004; Table 1). Subsequently, WHYMAP was the first to present a world-wide TBA map (Struckmeier et al. 2006). In 2009, the inter-agency cooperation arising from ISARM (UNESCOFAO-IAH-UNECE) with the support of IGRAC marked 40 major TBA systems in Africa (Puri and Aureli 2009). Concurrently, IGRAC published a global TBA map for the 5th Water World Water forum in Istanbul, Turkey (IGRAC 2009) identifying a total of 41 African TBAs. Unfortunately, there is no harmonisation in the labelling system used for TBAs of the three maps and associated databases. In 2012, IGRAC presented an updated version of the global TBA map at the 6th Water World forum in Marseille, France (IGRAC 2012a). This map shows 71 aquifers in Africa (Table 1), and the ID numbers (consisting of a pre-fix of 


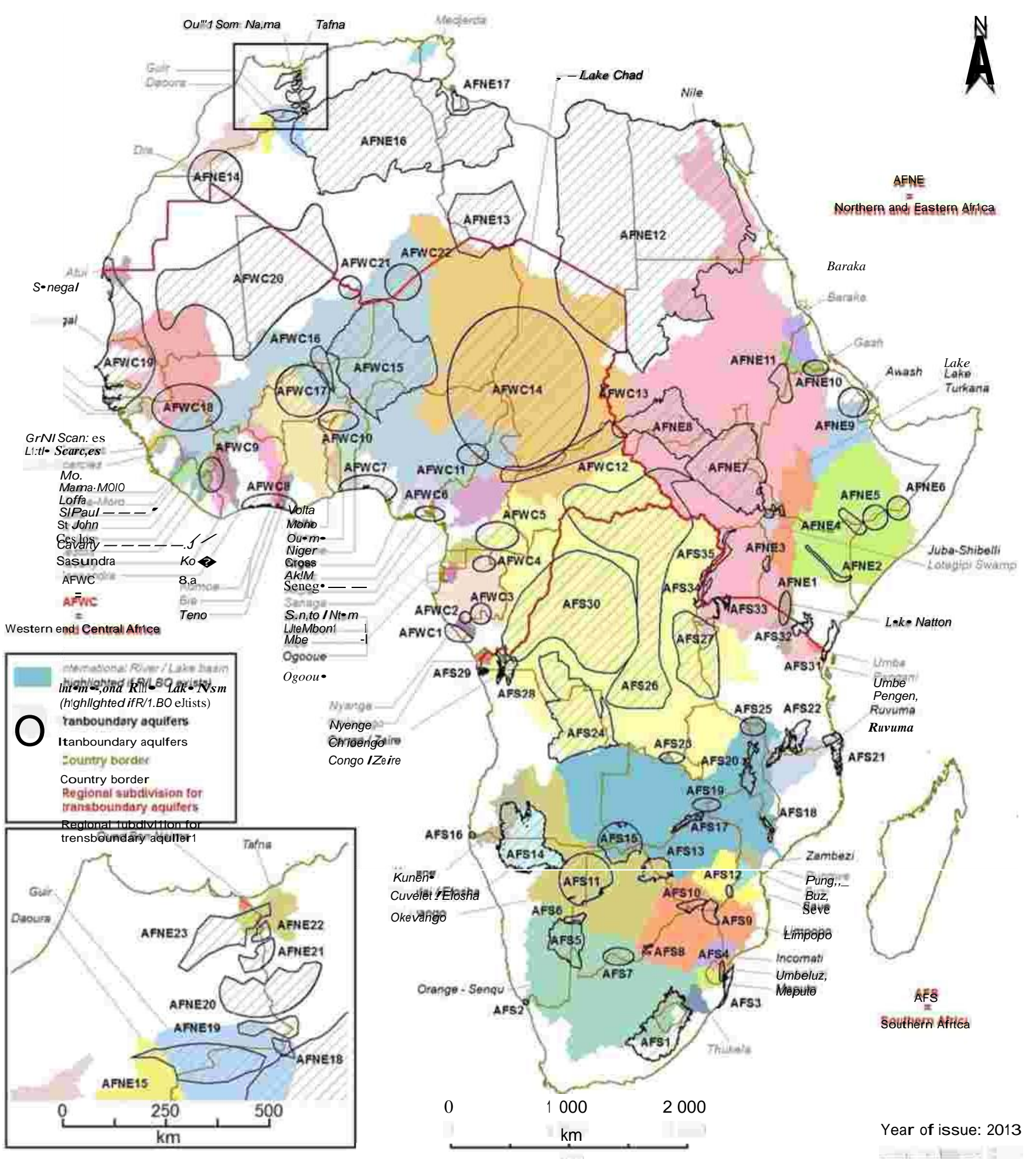

Fig. 1 Transboundary aquifers and international river/lake basins in Africa (see also Appendix)

letters signifying the region/continent and a number) given to the aquifers were changed compared to the 2009 map. In the 2012 map, the ID numbers are actually given starting with 1 in the south east of the continent and finishing with 71 in the north west of the continent; whereas in 2009, the ID numbers are more random, e.g. in the SADC region, increasing from north to south-with some discontinuity when new aquifers are identified - then for the rest of the continent the ID numbers increase from north to south also with some randomness. 
Table 1 Evolution of the number of TBAs in Africa, inventoried and mapped by various efforts and subdivided into regions

\begin{tabular}{|c|c|c|c|c|c|}
\hline African region $^{\mathrm{a}}$ & $\begin{array}{l}\text { UNESCO } \\
2004\end{array}$ & $\begin{array}{l}\text { WHYMAP } \\
2006\end{array}$ & $\begin{array}{l}\text { IGRAC } \\
2009\end{array}$ & $\begin{array}{l}\text { IGRAC } \\
2012 \mathrm{a}\end{array}$ & $\begin{array}{l}\text { This report } \\
2012\end{array}$ \\
\hline North Africa & 6 & 6 & 7 & 9 & 15 \\
\hline Western and Central Africa (except countries in SADC ${ }^{\mathrm{b}}$ ) & 9 & 9 & 9 & 22 & 22 \\
\hline Eastern Africa (except countries in SADC) & 5 & 5 & 5 & 6 & 8 \\
\hline Southern Africa (SADC countries) & 18 & 20 & 20 & 34 & 35 \\
\hline Total & 38 & 40 & 41 & 71 & 80 \\
\hline
\end{tabular}

${ }^{a}$ According to United Nations sub-region definition (UN data 2013)

${ }^{\mathrm{b}}$ SADC Southern African Development Community

Table 1 shows the evolution in the number of TBAs inventoried by ISARM, WHYMAP and IGRAC during the last decade. A significant increase in numbers is noticed in Southern Africa and Western/Central Africa, due primarily to activities of ISARM in both areas. As has been done in Southern Africa in collaboration with SADC, the work of ISARM is presently planned to improve the identification and delineation of the TBAs in Central/Western (First ISARM Central Africa and Second ISARM West Africa Workshop in Douala, Cameroon; 16-19 May 2011), and East Africa - the Sahara and Sahel Observatory (OSS) currently implements the "Mapping, Assessment and Management of Transboundary Water Resources in the IGAD sub-region (MAM/IGAD)" project (IGRAC 2012a).

Disparity and non-uniqueness in labelling systems as well as inconsistency in the numbering of newly identified TBAs in Africa relative to their location makes it relatively difficult to locate these aquifers and prompts the need for a more harmonised and systematic nomenclature and labelling system. The scheme proposed here divides Africa into three regions (Northern/Eastern Africa, Western/Central Africa and Southern Africa; Table 2; Fig. 1), each with its own unique ID and consecutive numbering scheme. The system facilitates the labelling of new aquifers and the localizing of existing aquifers. The subdivision acknowledges the importance and efforts of the regional economic communities (RECs) in Africa in terms of transboundary water resources management and regional integration (Granit 2010; Öjendal et al. 2010). Each zone has an abbreviation (AFNE, AFWC and AFS) used as a pre-fix for the TBA number. These prefixes have been inspired by IGRAC, which uses the AF prefix for the African TBAs. As a primary nomenclature, acknowledging that new numbers may break this pattern, TBA numbering is done in an east-west and south-north pattern starting with 1 in the south east part of the zone and finishing in the north west of the zone, adhering to the IGRAC-2012 version. Hence, the main difference in the new system is that TBA IDs include a regional location identifier as well as a continental signature.

The zone separation is based on existing RECs, their active involvement in transboundary water-resources management (Table 2), the riparian countries of major river basins (i.e. Niger and Nile) and similarity in climatic conditions. Equality in the number of identified TBAs in each zone is considered as well. For example, Eastern and Northern Africa form one area because of the non-negligible number of TBAs in the Nile River basin in Eastern Africa.
Likewise, Western and Central Africa are coalesced into one region, despite climatic differences, in order to maintain a similar number of TBAs in each region. Each TBA is classified into one of these three zones based on the location of the majority of its surface area within the regions sharing it. Hence, for example the Disa aquifer (AFWC13, in Fig. 1 and Appendix) fully located in the Lake Chad basin belongs to the AFWC zone, and the Mourzouk-Djado basin (AFNE13) mainly located in Libya is classified in the AFNE zone. Figure 1 shows the map of the 80 TBAs currently identified in Africa using the new nomenclature, and the Appendix presents a table of the TBAs including different names used in the literature for individual aquifers as well as some hydrogeological data and information on the aquifers (aquifer rock type, mean annual rainfall, and recharge) when available from the literature. Using the proposed nomenclature, new TBAs can easily be added in each zone with subsequent consecutive numbers. The main advantage of the proposed scheme is that it logically and systematically facilitates the location of existing TBAs as well as the specification of unique IDs to new aquifers. It is likely that such regionalisation and use of a similar ID system for TBAs are possible and beneficial for other continents as well.

In the Appendix, one main name for each aquifer is highlighted to suggest a single common accepted name for the TBAs. The objective is to reduce confusion because different aquifer names exist in the literature for the same aquifer. Some reasons for different names stem from:

- Improvement in the identification and delineation of the aquifers as being transboundary in nature, e.g. the separation of one TBA into several TBAs (e.g. AFNE18 to AFNE23) or the union of two or more aquifers into one TBA (e.g. Northern Kalahari/Karoo basin, AFS11)

- Co-existence of names reflecting the transboundary aquifer and names referring to the local/national/town association of the aquifer (e.g. Nata Karoo sub-basin, AFS15)

- Discrepancy in TBA names across borders due to difference in spelling of, e.g. rivers giving names to aquifers

A few TBAs (mainly in the Central/Western region) only have an ID but do not have a name (marked with ? in the Appendix). This can be explained by the presently preliminary assessment of these resources. The Appendix gives 
Table 2 The proposed regional sub-division for TBA nomenclature in Africa

\begin{tabular}{|c|c|c|}
\hline $\begin{array}{l}\text { Sub-division zone name } \\
\text { (code name) }\end{array}$ & African continental countries & $\begin{array}{l}\text { Regional economic } \\
\text { communities (RECs) } \\
\text { concerned }^{\mathrm{a}}\end{array}$ \\
\hline $\begin{array}{l}\text { Northern and Eastern Africa } \\
\text { (AFNE) }\end{array}$ & $\begin{array}{l}\text { Algeria, Diibouti, Egypt, Eritrea, Ethiopia, Kenva, Libya, Morocco, } \\
\text { Somalia, South Sudan, Sudan, Tunisia, Uganda and Western Sahara }\end{array}$ & $\begin{array}{l}\operatorname{IGAD}^{\mathrm{b}}(\mathrm{A}) \\
\operatorname{COMESA}^{\mathrm{c}}(\mathrm{PA}) \\
\mathrm{CEN}^{\mathrm{d}} \mathrm{SAD}^{\mathrm{d}}(\mathrm{PA}) \\
\text { EAC }^{\mathrm{e}}(\mathrm{PA}) \\
\operatorname{AMU}^{\mathrm{f}}(\mathrm{N})\end{array}$ \\
\hline $\begin{array}{l}\text { Central and Western Africa } \\
\text { (AFWC) }\end{array}$ & $\begin{array}{l}\text { Republic of Benin, Burkina Faso, Cameroon, Central African Republic } \\
\text { (CAR), Chad, Republic of the Congo, Republic of Côte d'Ivoire, Equatorial } \\
\text { Guinea, Gabon, Republic of Gambia, Republic of Ghana, The Republic of } \\
\text { Guinea, The Republic of Guinea Bissau, The Republic of Liberia, Republic } \\
\text { of Mali, Mauritania, Republic of Niger, Federal Republic of Nigeria, } \\
\text { Republic of Senegal, Republic of Sierra Leone and Togolese Republic }\end{array}$ & $\begin{array}{l}\operatorname{ECOWAS}^{\mathrm{g}}(\mathrm{A}) \\
\text { ECCAS }^{\mathrm{h}}(\mathrm{PA}) \\
\text { CEN-SAD }(\mathrm{PA}) \\
\text { AMU (N) }\end{array}$ \\
\hline Southern Africa (AFS) & $\begin{array}{l}\text { Angola, Botswana, Burundi, Democratic Republic of Congo (DRC), } \\
\text { Lesotho, Madagascar, Malawi, Mozambique, Namibia, Rwanda, South } \\
\text { Africa, Swaziland, United Republic of Tanzania, Zambia and Zimbabwe }\end{array}$ & $\begin{array}{l}\operatorname{SADC}^{\mathrm{i}}(\mathrm{A}) \\
\text { COMESA (PA) } \\
\text { EAC (PA) }\end{array}$ \\
\hline
\end{tabular}

${ }^{a}$ A active; PA poorly active; $\mathrm{N}$ non-active in transboundary water resources management, according to NEPAD et al. 2011

${ }^{\mathrm{b}}$ Intergovernmental Authority on Development: Djibouti, Eritrea, Ethiopia, Kenya, Somalia, South Sudan, Sudan and Uganda

${ }^{\mathrm{c}}$ Common Market for Eastern and Southern Africa: Burundi, Democratic Republic of Congo, Egypt, Ethiopia, Kenya, Libya, Malawi, Rwanda, South Sudan, Sudan Swaziland, Uganda, Zambia and Zimbabwe

${ }^{\mathrm{d}}$ Community of Sahel-Saharan States: Republic of Benin, Burkina Faso, Central African Republic (CAR), Chad, Republic of Côte d'Ivoire, Djibouti, Eritrea, Republic of Gambia, Republic of Ghana, The Republic of Guinea, The Republic of Guinea Bissau, Kenya, The Republic of Liberia, Libya, Republic of Mali, Mauritania, Morocco, Republic of Niger, Federal Republic of Nigeria, Republic of Senegal, Republic of Sierra Leone, Somalia, Sudan, Togolese Republic and Tunisia

${ }^{\mathrm{e}}$ East African Community: Burundi, Kenya, Republic of Tanzania, Rwanda, Uganda

${ }^{\mathrm{f}}$ Arab Maghreb Union: Algeria, Libya, Mauritania, Morocco, Tunisia and Western Sahara

${ }^{g}$ Economic Community of West African States: Republic of Benin, Burkina Faso, Republic of Côte d'Ivoire, Republic of Gambia, Republic of Ghana, The Republic of Guinea, The Republic of Guinea Bissau, The Republic of Liberia, Republic of Mali, Republic of Niger, Federal Republic of Nigeria, Republic of Senegal, Republic of Sierra Leone and Togolese Republic

${ }^{\mathrm{h}}$ Economic Community of Central African States: Cameroon, Central African Republic (CAR), Chad, Republic of the Congo, Equatorial Guinea and Gabon

${ }^{\mathrm{i}}$ Southern African Development Community: Angola, Botswana, Democratic Republic of Congo (DRC), Lesotho, Madagascar, Malawi, Mozambique, Namibia, South Africa, Swaziland, United Republic of Tanzania, Zambia, and Zimbabwe

approximate figures for population (UNEP 2000) and area for each TBA (determined from various database sources) in order to highlight the importance of the TBAs in Africa. Results show that the TBAs represent approximately $42 \%$ of continental Africa's land area and $30 \%$ of the population, which can be compared to $45 \%$ of area (Wolf et al. 1999) and $69 \%$ of population (this study) for the 63 international river basins in Africa. There is a huge difference between the aquifers in terms of population living within individual TBAs, reaching approximately 63 million in the case of the Nubian Sandstone aquifer system (AFNE12) to less than a hundred inhabitants (Coastal Sedimentary basin 4, AFS16; and L'Air Cristalline aquifer, AFWC21). The same heterogeneity exists in terms of areal extent, which can be smaller than $1,500 \mathrm{~km}^{2}$ (Jbel El Hamra aquifer, AFNE22 and Figuig aquifer, AFNE18) and larger than 2.6 mill. $\mathrm{km}^{2}$ (Nubian Sandstone aquifer system, AFNE12). The latter is comparable to the size of the Lake Chad River basin $\left(2.4\right.$ mill. $\left.\mathrm{km}^{2}\right)$. TBAs are shared between two and up to eight states, the latter being the case for the Lake Chad basin (AFWC14). In addition, Table 3 gives approximate figures for the percentage of the country area lying within TBA basins.
Difficulties in TBAs identification and delineation typically arise from the common-place unilateral study of the aquifers, if any at present. A typical example is the South 
West Kalahari/Karoo aquifer (AFS5) shared by South Africa, Botswana and Namibia. Namibia has investigated the aquifer since 1915, while limited information about this aquifer is available from the two other riparian countries, probably because of earlier lack of interest in this resource due to water-quality degradation toward South Africa and Botswana and limited human development in these areas (Alker 2008a). Few integrated international studies on TBAs have been done and the existing studies are mostly on the North Western Sahara aquifer system (AFNE16) and the Irhazer-Iullemeden basin (AFWC15), through studies coordinated by the Sahara and Sahel Observatory (OSS; i.e. the UNEP/OSS/GEF Iullemeden Aquifer Project and the UNEP/OSS/GEF Northwest Sahara Aquifer Project), as well as the Nubian Sandstone aquifer system (AFNE12).

As part of the on-going process of TBA identification and mapping, the map proposed in this report presents, based on a thorough literature review, 80 TBAs in Africa. The nine additional TBAs included compared to the IGRAC 2012 map derive from the following observations:

- The International Network of Water-Environment Centre for the Balkans (INWEB), which mapped the TBAs in the Mediterranean states, presents fifteen TBA systems in the Northern African region (INWEB 
Table 3 Approximate percentage of country area located within TBAs in Africa

\begin{tabular}{|c|c|c|c|c|c|}
\hline Country & $\begin{array}{l}\text { Percentage }(\%) \text { of } \\
\text { country area within } \\
\text { TBAs }\end{array}$ & Country & $\begin{array}{l}\text { Percentage }(\%) \text { of } \\
\text { country area within } \\
\text { TBAs }\end{array}$ & Country & $\begin{array}{l}\text { Percentage }(\%) \text { of } \\
\text { country area within } \\
\text { TBAs }\end{array}$ \\
\hline Algeria & 41 & Gabon & 16 & Rwanda & 24 \\
\hline Angola & 24 & Gambia & 100 & Senegal & 84 \\
\hline Benin & 30 & Ghana & 5 & Sierra Leone & 0 \\
\hline Botswana & 23 & Guinea & 40 & Somalia & 5 \\
\hline Burkina Faso & 55 & Guinea Bissau & 41 & South Africa & 12 \\
\hline Burundi & 86 & Kenya & 9 & South Sudan & 81 \\
\hline Cameroon & 36 & Lesotho & 100 & Sudan & 32 \\
\hline CAR & 43 & Liberia & 11 & Swaziland & 12 \\
\hline Chad & 73 & Libya & 72 & Tanzania & 13 \\
\hline DRC & 65 & Malawi & 29 & Togo & 10 \\
\hline Republic of Congo & 34 & Mali & 47 & Tunisia & 47 \\
\hline Cote d'Ivoire & 15 & Mauritania & 42 & Uganda & 9 \\
\hline Djibouti & 28 & Morocco & 15 & Zambia & 8 \\
\hline Egypt & 89 & Mozambique & 5 & Zimbabwe & 11 \\
\hline Equatorial Guinea & 0 & Namibia & 28 & Western Sahara & 12 \\
\hline Eritrea & 13 & Niger & 51 & & \\
\hline Ethiopia & 10 & Nigeria & 33 & & \\
\hline
\end{tabular}

2012), while the IGRAC database shows only nine, principally due to smaller aquifers between Algeria and Morocco indicated, rather than delineated. The six additional aquifers shared between these countries are AFNE18-AFNE23

- The identified "Rift aquifer", shared by Kenya, Tanzania and Uganda, has been deleted on the IGRAC 2012 map compared to the 2009 version. However, regardless of poor water quality (Lake Natron and Lake Magadi are not freshwater) and low groundwater potential (Mwango et al. 2004; Kashaigili 2010), groundwater flow seems to exist from Lake Naivasha to Lake Magadi (Becht et al. 2006) as well as a hydrogeological link between Lake Natron and Lake Magadi (Hillaire-Marcel and Casanova 1987). AFNE1 has been added to Fig. 1 to reflect this.

- Abiye (2010) identified and discussed the TBAs in East Africa. He included a transboundary aquifer, here called the Mareb aquifer for lack of other published name, between Eritrea and Ethiopia, which is not present on the IGRAC 2012 map; thus, the AFNE10 has been added.

- Rahube (2003) worked on the recharge and groundwater resources of Lokalane-Ncojane basin (between Botswana and Namibia). This work shows that a TBA exists in the region of the Ncojane basin. Location of this aquifer does not seem to coincide with the delineation of the SW Kalahari/Karoo basin nearby (AFS5). Hence, AFS6 (Fig. 1) has been added as an individual TBA though additional work may be needed to verify its separate unity.

The updated map in Fig. 1 depicts the delineation of TBAs according to the best available knowledge. Hence, where boundaries are well known (and in most cases agreed by coriparians), the TBAs are shown as polygons. In cases where the boundaries are not well known, the TBAs are given as circles or ellipses. Due to uncertainty in boundaries, overlap of some TBAs appears. Also, TBA polygon shape shows more details in TBA delineation in the AFS area and in Northern Africa, indicating relatively advanced delineation in these areas. The additional nine aquifers in Fig. 1 relative to
IGRAC map will have to be reaffirmed and consolidated through their mapping and consultation processes.

\section{Transboundary aquifer management: an emerging framework}

The complexities and diversity in TBA physical and hydraulic configurations entail challenges for mapping that are distinct from surface-water courses. These challenges are increasingly explored in an attempt to develop typologies, indicators, and associated best-management strategies (UNESCO-IHP 2011; Scheumann and Alker 2009; UNECE 2007; Jarvis et al. 2005; Eckstein and Eckstein 2003b; Barberis 1991). Still, groundwater that transcends international borders is a critical missing link in attaining a truly integrated approach to transboundary water-resources management (TWM), which has hitherto been totally dominated by a surface-water focus, practically ignoring the intricate and almost ubiquitous interconnectedness between these systems.

Globally, experience with practical TBA management is limited (Eckstein 2011), and Africa is no exception (Eckstein 2011; Scheumann and Herrfahrdt-Pähle 2008). Having said this, there is currently a strong drive from the international donor community as well as some of the African countries themselves to leverage increased efforts and to include TBA management into holistic TWM (Aureli and Eckstein 2011; Stephan 2009). The approach is currently mostly pre-emptive in the sense that significant conflicts over shared aquifers are not apparent or are still not fully documented in terms of extent and underlying causes (Scheumann and Alker 2009). A critical prerequisite for better grasping the risk and implications of conflict is through increased understanding of the resource and the human interaction and impacts on it and associated dependent systems, which for the most part is missing, or emerging in Africa.

Groundwater in Africa has traditionally been associated with rural water supply and drought prevention through 
dispersed schemes and low abstraction rates (mostly SubSaharan Africa), or more intensive use associated with development for urban use and larger-scale irrigation (mostly Northern Africa). While this image is slowly changing, with increasing attention to and demand for groundwater development for urban and industrial use and irrigation, as well as climate change, at various scales in Sub-Saharan Africa, TBAs will no doubt in the future play a significant role in meeting increased water demands for multiple purposes. Hence, an increased focus on TBA management is fully warranted and has to transcend the traditional ways of viewing groundwater, namely as a small-scale extensive use source. TBAs, and groundwater in general in Africa, will have to serve multiple uses at various scales and levels of development and often simultaneously within the same geographic locations. Furthermore, reconciling such development with significant ecosystem dependence on groundwater at local and transboundary scale for the inherent value of these systems and for the sustained human reliance on them is a major challenge in Africa, where only recently an understanding of these groundwater-dependent ecosystems and required environmental flows and characteristics related to groundwater is emerging (Colvin et al. 2007).

On-going challenges associated with TBA management in Africa are related to:

1. Identifying, delimiting and understanding TBAs

2. Developing appropriate legal frameworks for their joint and sustainable management

3. Developing appropriate institutional setups

4. Ensuring that development and benefits from TBA are inclusive and equitable

In the following, each of these challenges is briefly discussed, along with present progress and requirements to proceed.

\section{Identifying, delimiting and understanding TBAs}

Transboundary aquifers are inherently not different from other aquifers. Their distinguishing character pertains to the fact that they cross international borders implying complexities in their optimal management. Many of these aquifers, however, to have more than local management interest, are relatively large and may have regional deep subsurface flow characteristics (Tóth 1963), lending themselves to the need for understanding the implications of far-reaching often slow lateral inter-basin flow processes (e.g. Gleeson and Manning 2008) besides any interactions with surface-water bodies.

The unit of management, equivalent to the river basin in traditional river-basin management, is critical to ascertain and map. Initial efforts by IGRAC and ISARM developed strategies for these processes, involving converging national and emerging regional and continental geological maps (Vasak and Kukuric 2006; Puri and Aureli 2005). Increasingly, modern hydrogeological technologies like tracer and isotope studies (Wang et al. 2010), air-borne geophysics (Siemon et al. 2005) and satellite-based remote sensing
(Saradeth et al. 2010; Marsala et al. 2009) are used to complement more traditional hydrogeological studies, though a more transboundary focus is warranted. Joint crossboundary interpretation and harmonisation of maps along with characterisation of the border region from hydrogeophysical as well as socio-economical perspectives helps develop an overall conceptual model of the aquifer or aquifer system (Jarvis 2006). The need for pursuing a multidisciplinary, consultative and dynamic process in delineating and characterising a TBA in order to address complexities, uncertainties and changes in states, processes and stress factors at TBA-system scale, as well as those that capture the social, economic and governance factors associated with human impacts on the TBAs is increasingly acknowledged (UNESCO-IHP 2011; Jarvis 2006). Emphasis on consensus and transparency regarding a preliminary delineation and a conceptual model may be more conducive for further joint assessment of a TBA, and hence reducing uncertainties, than excessive emphasis on a detailed but less open and shared assessment by one or a sub-set of stakeholders. Data on TBAs in Africa reside with national institutions, transboundary R/ LBOs, and newly developed data sharing mechanisms related to specific TBAs (see next section) as well as international organisations like IGRAC.

Developing appropriate legal frameworks for joint and sustainable management of TBAs

Legal frameworks for TWM continually evolve, reflecting a growing understanding of best practices and pertinent principles and issues (Giordano et al. 2013; Conca et al. 2006). The topic of groundwater illustrates this very well. Prior to 1950 , practically no attention was paid to groundwater in TWM agreements (Giordano et al. 2013). Increasingly, groundwater attains significance in treaties, with explicit mentioning and dedicated agreements with specific groundwater provisions (Eckstein 2011; Burchi and Mechlem 2005). However, despite significant efforts to harmonise the UN Convention on the Law of the Non-Navigational Uses of International Watercourses (UNWCC; United Nations 1997) and the UNILC Draft Articles on TBAs (the UNILC Draft Articles take the UNWCC as a starting point in an effort to harmonise international rules on water resources and the UNWCC was based on articles drafted by the UNILC), there is still a significant stride to be achieved in obtaining a fully integrated and holistic approach to the various water systems in international law. This is due to the early exclusive focus on the visible water resources (international rivers and later also lakes), lack of understanding of groundwater functioning among legislators, legal scholars and policy makers (Eckstein and Eckstein 2003b), and the tardiness of adjusting existing international law despite growing recognition of the needs to do so (Cooley et al. 2009).

Notwithstanding the fact that the United Nations Economic Commission for Europe's Convention on the Protection and Use of Transboundary Watercourses and International Lakes (The UNECE Water Convention; UNECE 1992) is soon to be open for universal accession (GWP 2013), there are presently 
basically two options to adopt groundwater into international agreements based on international law, albeit neither is currently in force: either by adopting the 1997 UNWCC (presently ratified by 10 parties to the Convention out of 35 required for it to enter into force; International Water Law Project 2013), which defines groundwater as a physical extension of the surface-water body within the watercourse spatial domain, or by using the 19 Draft Articles on the Law of Transboundary Aquifers (still not adopted by the UN General Assembly, UNGA). The discrepancies and insufficiencies in terms of addressing groundwater universally with the UNWCC relates to the fact that an aquifer does not comply with the notion of 'normally flowing into a common terminus' as the river system does, and its boundaries do not necessarily conform with the river basin. In addition, some aquifers may not be associated with a traditional water course as, e.g. fossil or 'confined' groundwater (Eckstein and Eckstein 2003b). Confined groundwater here refers to water contained in aquifers that does not relate to surface water (McCaffrey 2011: Eckstein and Eckstein 2003b; UNGA 2003), which potentially causes confusion on applicability as it is inconsistent with conventional hydrogeology terminology. To partly compensate for these legal deficiencies, the UN International Law Commission (UNILC) has developed - in consultation and collaboration with technical and hydrogeological partners, like UNESCO, IAH, FAO, UNECE (UNGA 2003) - and proposed for adoption to the UNGA a set of 19 Draft Articles on the Law of Transboundary Aquifers (Stephan 2009; United Nations 2008). These draft articles, the final form of which (convention or guidance document) is still pending a decision by the UNGA at its 68th session in 2013 (Eckstein 2011) in order to potentially have legally binding character, focus on the transboundary aquifers and hence fill a significant gap in international water law. They are quite comprehensive and include direct mentioning of aquifer relationships with surface-water courses and ecosystems and, hence, are presently the most comprehensive, albeit debated (Dellapenna 2011; McCaffrey 2011), set of international legislation available for TBAs. In the interim, the UNGA promotes bilateral or regional agreements between countries sharing aquifer systems (UNGA 2012). The Guarani aquifer in South America is the first legal agreement based on the Draft Articles (Villar and Ribeiro 2011).

In Africa, legal agreements on groundwater are evolving, like in most parts of the world (Aureli and Eckstein 2011; Stephan 2009). Examples exist in the multilateral agreements to explicitly share data, jointly perform diagnostic analysis on TBAs, and to develop joint consultation mechanisms as a precursor for more formalised joint-management frameworks and institutions. Cases in point are the Nubian Sandstone Aquifer system (AFNE12) (agreement from 2000), North Western Sahara Aquifer system (AFNE16) (agreement from 2002) (GEF 2012; Eckstein 2011; Stephan 2009; Burchi and Mechlem 2005), and Irhazer-Iullemeden (AFWC15) (agreement from 2009) (Eckstein 2011), while Orange-Senqu River basin, and Lake Victoria basin have a high degree of focus on groundwater in their shared R/LBs (Braune and Xu 2011). The first three pertain explicitly to the aquifers, while the latter two hinge on existing river/lake basin organisations (R/LBOs) and their formalised agreements. Collaboration and present initiatives, not surprisingly, tend to reflect the importance and value of groundwater in more arid water-deficient areas with few or limited surface-water resources. They also reflect priorities of international donors and institutions, presently putting TWM high on the development agenda (GWP 2013; GEF 2012; UNWATER 2008) and growing national awareness in critical areas or basins. Creating or revising legal frameworks for international cooperation on specific shared water courses is a tedious process, especially if the water-resource issues are contentious (e.g. the Nile River case, Cascão 2010). While initial efforts to bring partners together around improving the knowledge base may be relatively easy and facilitate trust building for potentially developing further agreements (Linton and Brooks 2011; Aureli and Eckstein 2011; Scheumann and HerrfahrdtPähle 2008), there is also a risk of losing momentum as the legal and political processes stall as seems to be the case for the Iullemeden aquifer system (International Water Law Project 2012), indicating the need for sustained support from international donors. It also points to the need of addressing critical TBAs at a point when mutual interest is expressed but while significant disputes have not evolved.

RECs, as part of their strategy for regional integration and development, and poverty alleviation, promote international natural resource, and specifically water, management as a means to foster sustainable development (Öjendal et al. 2010). SADC is taking a frontrunner position in this respect, with a dedicated Regional Strategic Action Plan (RSAP) for integrated water-resources management (SADC 2011), explicitly addressing TBA management, through transboundary diagnostic analysis and strategic action plans, as part of an ongoing groundwater-management programme in the region. This programme is overseen by a sub-committee on hydrogeology, which has also developed a guideline for groundwater development in the region (SADC-WSCU 2001). Furthermore, SADC has adopted the Protocol on Shared Watercourses in 1995 (with a revision in 2000; SADC 1995), which hinges on the UNWCC mentioned earlier (Braune and $\mathrm{Xu}$ 2011). The Protocol seeks 'to promote and facilitate the establishment of shared watercourse agreements and shared watercourse institutions for the management of shared watercourses' (SADC 2000). SADC is presently contemplating how to adopt the Draft Articles on the Law of TBAs (Braune and Xu 2011; UNESCO-IHP 2009). Furthermore, work is in progress in SADC to identify 'troublesome' TBAs in order to accord prioritised support (Davies et al. 2012) and on piloting harmonised and up- and out-scalable solutions to TBA management (SADC 2011; Christelis et al. 2010). Several TBA-relevant outputs of the SADC groundwater management programme have come out, including a region-wide seamless map of groundwater drought risk (Villholth et al. 2013).

\section{Developing appropriate institutional setups}

Establishing efficient and effective organisations for the management of TBAs is essential, and important lessons may be learned from experiences of R/LBOs in addressing 
TWM (Schmeier 2010). In fact, the African Ministers' Council on Water (AMCOW) recommended in 2007 the R/ LBOs as the nucleus for TBA management in Africa (Braune and $\mathrm{Xu}$ 2011). The immediate argument for this is their present integral role as custodians for shared river and lake-basin resources and the added advantage and options for further integration of the management of all hydrological resources in the same entity. Counterarguments include firstly that R/LBAs are not equipped, in terms of human capacity, financing, and authority, at present to take the responsibility of TBA management (Villholth and Vaessen 2013; Linton and Brooks 2011; NEPAD et al. 2011) and secondly that the geographical sphere of TBAs do not align with the spatial mandate of the R/LBOs (Schmeier 2010; Fig. 2). For some TBAs, international R/LBOs do not exist at all (18 cases according to Fig. 2, considering information on R/LBOs from AMCOW and ANBO 2007); hence, necessitating alternative management models. This can be because no R/LBO has yet been formalised for the area in question or because the TBA is located in an arid region with little perennial surface-water bodies, as in the case of some TBAs in Northern and Southern Africa. Figure 2, in conjunction with the listing of geographical types in the Appendix for the TBAs, may support first-hand geographical identification of possible international institutional management setups for individual TBAs; hence, creating a link between the mapping and the management framework put forward. However, it should be recognised that uncertainty prevails regarding the exact geographical boundaries of some TBAs.

Alternative solutions argue for the option of more localised management models suited to the particular scope and critical areas of the TBA and for the possibility to build particularly strong capacity on groundwater management in these areas (Scheumann and. Herrfahrdt-Pähle 2008; United Nations 2008). Yet, others argue for a strong involvement of the national authorities as the sovereignty aspect becomes critical in the management of cross-boundary water resources (Öjendal et al. 2010). Particularly for aquifers, this relates to extended issues of governance, with respect to, e.g. land use and geological, mineral, energy and sub-surface storage resources (Jarvis 2011). It becomes clear that an aquifer is more than the groundwater resource contained within it. So far, however, there persists ambiguity as to what the actual object of management is, whether the groundwater resource per se, or the broader resource along with its container, i.e. the geological formation. This is due to the use of the words 'groundwater' and 'aquifer' as synonyms in international law (Sanchez 2011). While beyond the scope of this report, the term used and the interpretation may, however, have farreaching future implications (Jarvis 2011).

Whichever institutional setup is chosen for particular TBAs will depend on the trade-off between these advantages and disadvantages and the geographic, hydrogeological, socio-economic, and political context. R/LBOs and RECs
Fig. 2 Conceptual configuration of TBA location in relation to international river and lake basins (R/LBs); polygons represent river/lake basins, squares represent TBAs

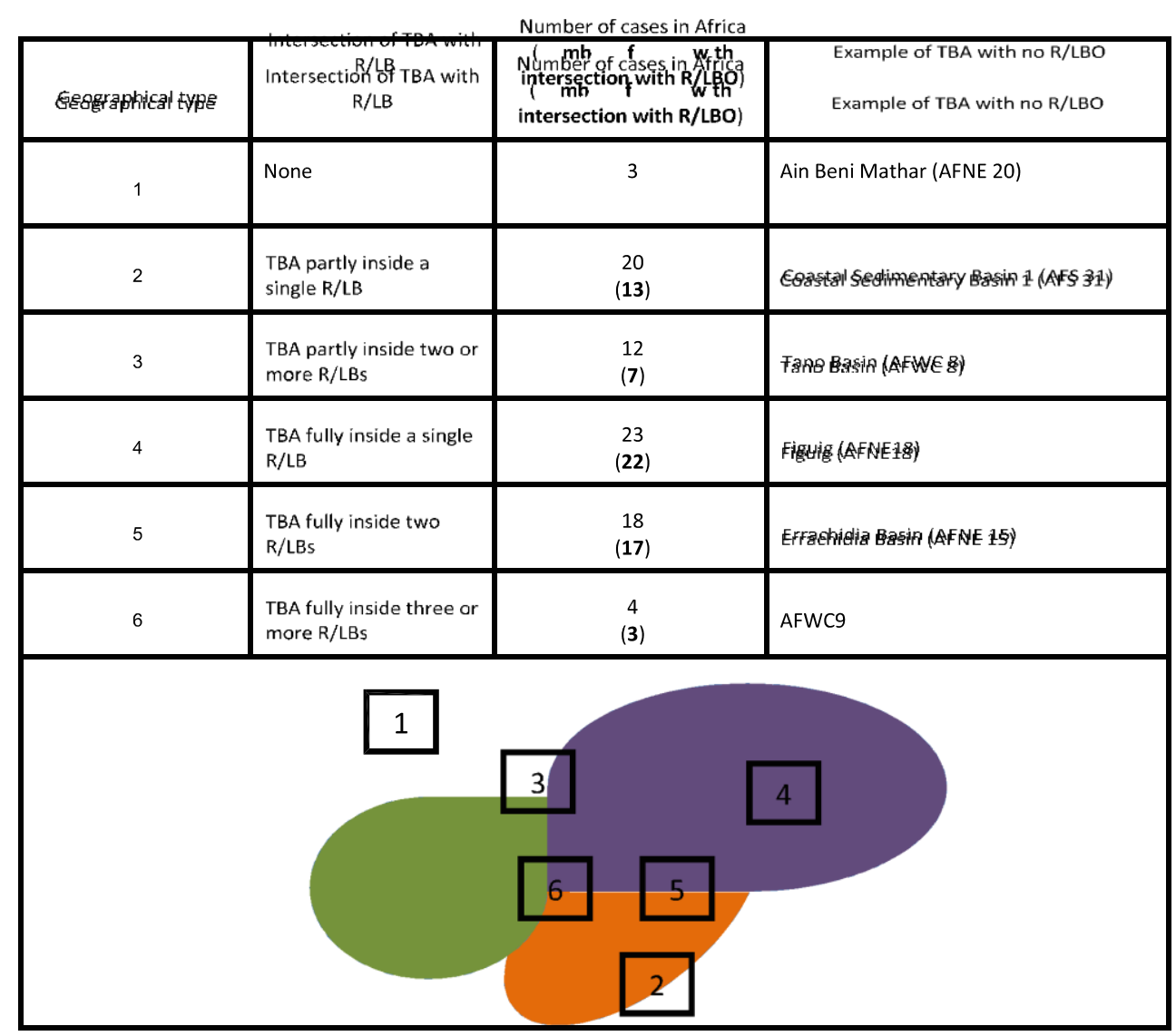

a TBA has no name according to IGRAC (2012) 
will undoubtedly play an increasing role in TBA management in Africa as part of a harmonised and integrated approach, and the process of equipping these institutions for this mandate will have to be aligned with general efforts to build the capacity of these institutions. However, some hybrid multilevel solutions will most probably emerge, as national institutions with established capacity in hydrogeology will need to be drafted upon, e.g. as part of R/LBO subcommittees on hydrogeology (Orange-Senqu is an example, Braune and $\mathrm{Xu} 2011$ ) to move informed management ahead, as well as to pledge national interests. Furthermore, increased cooperation between $\mathrm{R} / \mathrm{LBO}$ sill be required to address those TBAs that transcend more than one river basin (types 3 , 5, and 6 in Fig. 2). Finally, formalising management of TBAs at the international level may compromise more informal local level and traditional management approaches to groundwater that still have merit (Linton and Brooks 2011). This is an area of research that needs further attention.

\section{Ensuring inclusive and equitable development and benefits from TBAs}

In Africa in particular, poverty alleviation, food and water security, and climate resilience rank high on the national development agendas. Hence, ensuring the equitable and shared benefits of the water resources, and in this case TBAs, is essential in a long-term perspective as development and management frameworks emerge and mature (Puri and Aureli 2005). As often brought forward, groundwater holds many promises of democratic development and management as well as climate-proofed solutions due to its dispersed availability and large and protected storage characteristics. Hence, taking advantage of these properties, while protecting the resource and devolving the benefits to all spheres of society, is a key challenge. There may be a risk of focus on centralised and large-scale development benefitting certain sectors and sections of society if TBA development and management are conceived principally in an international context (Zeitoun and Jägerskog 2011). International development organisation may also inadvertently favour stronger parties, thereby entrenching existing power structures (Öjendal et al. 2010).

The nexus between TBAs and poverty alleviation has been recognised (Puri and Aureli 2005; Braune and Xu 2011), but requires significant further exploration. Some pointers can be derived from Zeitoun and Jägerskog (2011), who firstly hold that equitability in TWM (intraand internationally) is key to effective cooperation and poverty alleviation and secondly point to strategies and policies to counteract capture of benefits by hegemons (i.e. the stronger riparian states) and stronger stakeholders. These strategies and policies ensure, possibly by thirdparty intervention, capacity building among the least developed aquifer states (in order to level the 'players' or 'playing field') and, hence, to reduce asymmetry between countries, which is seen as a major compounding factor to slow progress on TWM and TBA management in Africa (Braune and Xu 2011). It also involves ensuring bottom-up approaches to identifying development demand, to ensure priority no-regret small-scale development (water supply, irrigation, drought proofing, etc.) in early phases of joint development and management, and to demonstrate visible impacts on the ground, as well as to prioritise stakeholder involvement in local management and protection of the resource (NEPAD et al. 2011; Alker 2008b). Furthermore, as groundwater lends itself to decentralised development, policies to enhance its management may support and facilitate decentralised development solutions, supporting rural development and offsetting prevailing urbanisation trends, which tend to overwhelm many African countries at present.

\section{Conclusion}

The report has evidenced significant advances in Africa with respect to mapping, legal frameworks, institutional development, and multilateral agreements pertaining to TBAs, reflecting the growing importance of these resources for development in the continent. Notwithstanding, TBA management is only recently addressed as part of TWM and it is critical to implement frameworks that can pre-empt disputes over shared groundwater or associated dependent eco-systems and human development. While a harmonised approach is advocated, it is also acknowledged that flexible and hybrid institutional models that build on the present customary approach of making the $\mathrm{R} / \mathrm{LBOs}$ responsible may be necessary. This is already evident and clearly required in Northern Africa where surface-water resources are secondary to groundwater.

Identification and mapping of TBAs is an ongoing and iterative process and the report suggests a regionalised approach to the mapping, which should facilitate the mapping of new aquifers and their inclusion into management efforts and strategies of relevant RECs. Furthermore, mapping TBAs conspicuously superimposed on R/LBs, and classifying TBAs according to intersection with these, facilitate early identification of geographically based best options for integrated management of surface and groundwater resources.

There is a need to address asymmetries in capacity, making the development and management of TBAs equitable across and within countries and making it pro-poor in a strategic and prioritised fashion. Pilot efforts need to strike a balance between bottom-up approaches and top-down efforts.

Conclusion of bilateral and regional agreements on TBAs and further development of international law on TBAs seem to concur in a parallel process, mutually reinforcing each other. While a truly integrated and comprehensive international legal framework for the holistic system of hydrological resources is the ideal and potential of the future, significant recent advances in covering transboundary groundwater in international law opens the opportunity to attain such instruments. For this, continued concerted inter-disciplinary collaboration between hydrogeologists and lawmakers is required.

Acknowledgements The authors would like to thank IGRAC for its support. This work has been funded partly by the Rockefeller Foundation and the French Ministry of Agriculture. 


\section{Appendix}

Table 4 Inventory of transboundary aquifers in Africa

\begin{tabular}{|c|c|c|c|c|c|c|c|c|c|c|c|c|c|c|}
\hline \multirow{2}{*}{$\begin{array}{l}\text { Proposed } \\
\text { ID }\end{array}$} & \multicolumn{3}{|c|}{$\begin{array}{l}\text { Reference nu nber } \\
\text { WHYMAP IGRAC }\end{array}$} & \multirow[b]{2}{*}{ INWEB } & \multirow{2}{*}{$\begin{array}{l}\text { Maingname } \\
\text { (other names }\end{array}$} & \multirow{2}{*}{$\begin{array}{l}\text { Countries } \\
\text { sharing }\end{array}$} & \multirow{2}{*}{$\begin{array}{l}\text { Major river basin } \\
\text { (sub-river basin) }\end{array}$} & \multirow{2}{*}{$\begin{array}{l}\text { Geographical } \\
\text { type (Fig. 2) }\end{array}$} & \multirow[t]{2}{*}{ Population $^{a}$} & \multirow{2}{*}{$\begin{array}{l}\text { Area } \\
\left(\mathrm{km}^{2}\right)^{\mathrm{b}}\end{array}$} & \multirow[t]{2}{*}{ Aquifer type } & \multirow{2}{*}{$\begin{array}{l}\text { Average } \\
\text { rainfall } \\
(\mathrm{mm} / \mathrm{a})^{\mathrm{c}}\end{array}$} & \multirow{2}{*}{$\begin{array}{l}\text { Annual recharge } \\
\text { (WHYMAP) }^{\mathrm{d}}\end{array}$} & \multirow{2}{*}{$\begin{array}{l}\text { Spquesesher } \\
\text { than IGRAC } \\
\text { or UNESCO }\end{array}$} \\
\hline & $\begin{array}{l}\text { WHYMAP } \\
2006\end{array}$ & $\frac{\text { IGRAC }}{2009}$ & 2012 & & & & & & & & & & & \\
\hline AFNE1 & 417 & 37 & NA & $\mathrm{NA}$ & Rift aquifer & $\begin{array}{l}\text { Kenya } \\
\text { Tanzania } \\
\text { Uganda }\end{array}$ & $\begin{array}{l}\text { Rift Valley (Lake } \\
\text { Natron, Lake } \\
\text { Navaisha/Turkana) } \\
\text { Nile (Nyando, Simiyu) }\end{array}$ & 6 & 279,000 & 21,150 & Volcanic & $450-1,100$ & Very low to medium & $\begin{array}{l}\text { Betch et al. } \\
2006\end{array}$ \\
\hline AFNE2 & 420 & 40 & NA & $\mathrm{NA}$ & $\begin{array}{l}\text { Merti aquifer } \\
\text { (Wabishebele and } \\
\text { Genale aquifer) }\end{array}$ & $\begin{array}{l}\text { Kenya } \\
\text { Somalia }\end{array}$ & $\begin{array}{l}\text { Shebelli and Juba } \\
\text { (Lak Dera) }\end{array}$ & 4 & 129,000 & 13,500 & $\begin{array}{l}\text { Semi-consolidated } \\
\text { sedimentary } \\
\text { (clays, sands, }\end{array}$ & $350-750$ & Low to medium & $\begin{array}{l}\text { Mumma } \\
\text { et al. 2011; } \\
\text { Mwango }\end{array}$ \\
\hline AFNE3 & 419 & 39 & 39 & NA & Mount Elgon & $\begin{array}{l}\text { Kenya } \\
\text { Uganda }\end{array}$ & $\begin{array}{l}\text { Nile (Victoria Nile, } \\
\text { Nyando) } \\
\text { Rift Valley (Lake } \\
\text { Turkana) }\end{array}$ & 5 & 806,550 & 5,400 & $\begin{array}{l}\text { Vodandiktones, } \\
\text { limestones) }\end{array}$ & $1,000-1,300$ & Very low to medium & $\begin{array}{r}\text { et al. 2002; } \\
\text { Krhoda 1989 }\end{array}$ \\
\hline AFNE4 & 418 & 38 or 49 & 43 & NA & $\begin{array}{l}\text { Dawa (part of } \\
\text { Ogaden-Juba } \\
\text { aquifer) }\end{array}$ & $\begin{array}{l}\text { Ethiopia } \\
\text { Kenya } \\
\text { Somalia }\end{array}$ & $\begin{array}{l}\text { Shebelli and Juba } \\
\text { (Dawa) }\end{array}$ & 4 & 223,150 & 24,000 & $\begin{array}{l}\text { Volcanic rocks, } \\
\text { alluvials and } \\
\text { Precambrian } \\
\text { basement }\end{array}$ & $300-650$ & Very low to low & Abiye 2010 \\
\hline AFNE5 & 418 & 38 or 50 & 44 & NA & $\begin{array}{l}\text { Juba aquifer (part } \\
\text { of Ogaden-Juba } \\
\text { aquifer) }\end{array}$ & $\begin{array}{l}\text { Ethiopia } \\
\text { Kenya } \\
\text { Somalia }\end{array}$ & $\begin{array}{l}\text { Shebelli and Juba } \\
\text { (Juba) }\end{array}$ & 4 & 197,600 & 34,600 & $\begin{array}{l}\text { Aquifers in } \\
\text { Precambrian and } \\
\text { intrusive rocks }\end{array}$ & $270-450$ & Very low to low & Abiye 2010 \\
\hline AFNE6 & 418 & 38 or 51 & 45 & NA & Shabelle aquifer & Ethiopia & Shebelli and Juba & 2 & 334,000 & 31,000 & Sedimentary and & $280-400$ & Very low to low & Abiye 2010 \\
\hline & & & & & $\begin{array}{l}\text { (part of Ogaden- } \\
\text { Juba aquifer) }\end{array}$ & Somalia & (Shebelli, Fafen) & & & & $\begin{array}{l}\text { minor volcanic } \\
\text { aquifers }\end{array}$ & & & \\
\hline AFNE7 & 415 & 35 or 45 & 46 & NA & Sudd basin (part & Ethiopia & Nile (Kwahr & 6 & $2,926,500$ & 331,600 & Aquifers in & $450-1,100$ & Medium & Abiye 2010 \\
\hline & & & & & of Upper Nile) & $\begin{array}{l}\text { Kenya } \\
\text { South Sudan } \\
\text { Sudan }\end{array}$ & $\begin{array}{l}\text { M'boloko, Sue, } \\
\text { White Nile, Kidepo, } \\
\text { Akoba, Khawr } \\
\text { Marchar, Khawr } \\
\text { Adar, Khawr Biban, } \\
\text { Khawr, Baro Wenz, } \\
\text { Khawr Kuteira, } \\
\text { Kwahr Tendik) } \\
\text { Rift Valley } \\
\text { (Lotagipi Swamp, } \\
\text { Lake Turkana) }\end{array}$ & & & & $\begin{array}{l}\text { Precambrian and } \\
\text { volcanic rocks } \\
\text { with patches of } \\
\text { alluvials along } \\
\text { valleys and deep } \\
\text { sedimentary } \\
\text { aquifers }\end{array}$ & & & \\
\hline AFNE8 & 415 & 35 or 46 & 53 & NA & $\begin{array}{l}\text { Baggara basin (part } \\
\text { of Upper Nile) }\end{array}$ & $\begin{array}{l}\text { CAR } \\
\text { South Sudan } \\
\text { Sudan }\end{array}$ & $\begin{array}{l}\text { Nile (Bandah, Al } \\
\text { Ghallah, Buharyrat } \\
\text { Abyad, White Nile, } \\
\text { Sue, Sopo, Bahr al } \\
\text { Arab, Al Ku) } \\
\text { Lake Chad (Oulou, } \\
\text { Bahr Azum) }\end{array}$ & 5 & $2,433,500$ & 239,300 & $\begin{array}{l}\text { Umm Ruwaba } \\
\text { formation which } \\
\text { is unconformable } \\
\text { overlain the } \\
\text { Nubian Formation. }\end{array}$ & $300-900$ & Low to medium & \\
\hline AFNE9 & 416 & 36 & 59 & NA & $\begin{array}{l}\text { Awash Valley } \\
\text { aquifer (African } \\
\text { Rift Valley } \\
\text { aquifer) }\end{array}$ & $\begin{array}{l}\text { Djibouti } \\
\text { Eritrea } \\
\text { Ethiopia }\end{array}$ & $\begin{array}{l}\text { Rift Valley (Afrera Ye } \\
\text { Chew Hayk, Awash, } \\
\text { Harewa/Arje) } \\
\text { North East Coast } \\
\text { (Alal, Erythrean } \\
\text { Coast) }\end{array}$ & 2 & 627,400 & 50,700 & Volcanic & $110-350$ & Very low to low & \\
\hline AFNE10 & NA & NA & NA & NA & $\begin{array}{l}\text { Mareb aquifer } \\
\text { (Name proposed) }\end{array}$ & $\begin{array}{l}\text { Eritrea } \\
\text { Ethiopia }\end{array}$ & $\begin{array}{l}\text { Gash (Mereb Wenz) } \\
\text { Baraka (Nahr Al Qash }\end{array}$ & 3 & $1,827,900$ & 22,800 & $\begin{array}{r}\text { Precambrian and } \\
\text { intrusive rocks }\end{array}$ & $450-550$ & Very low to medium & Abiye 2010 \\
\hline AFNE11 & NA & 48 & 61 & NA & Gedaref & Eritrea & Nile basin (Nahr & 4 & 732,000 & 38,700 & Aquifers in & $400-950$ & Very low to medium & Abiye 2010 \\
\hline & & & & & & $\begin{array}{l}\text { Ethiopia } \\
\text { Sudan }\end{array}$ & & & & & Atbarah, Nahı & ndar, Tekez & & \\
\hline
\end{tabular}


Precambrian and

volcanic rocks with

patches of alluvials 
Table 4 (continued)

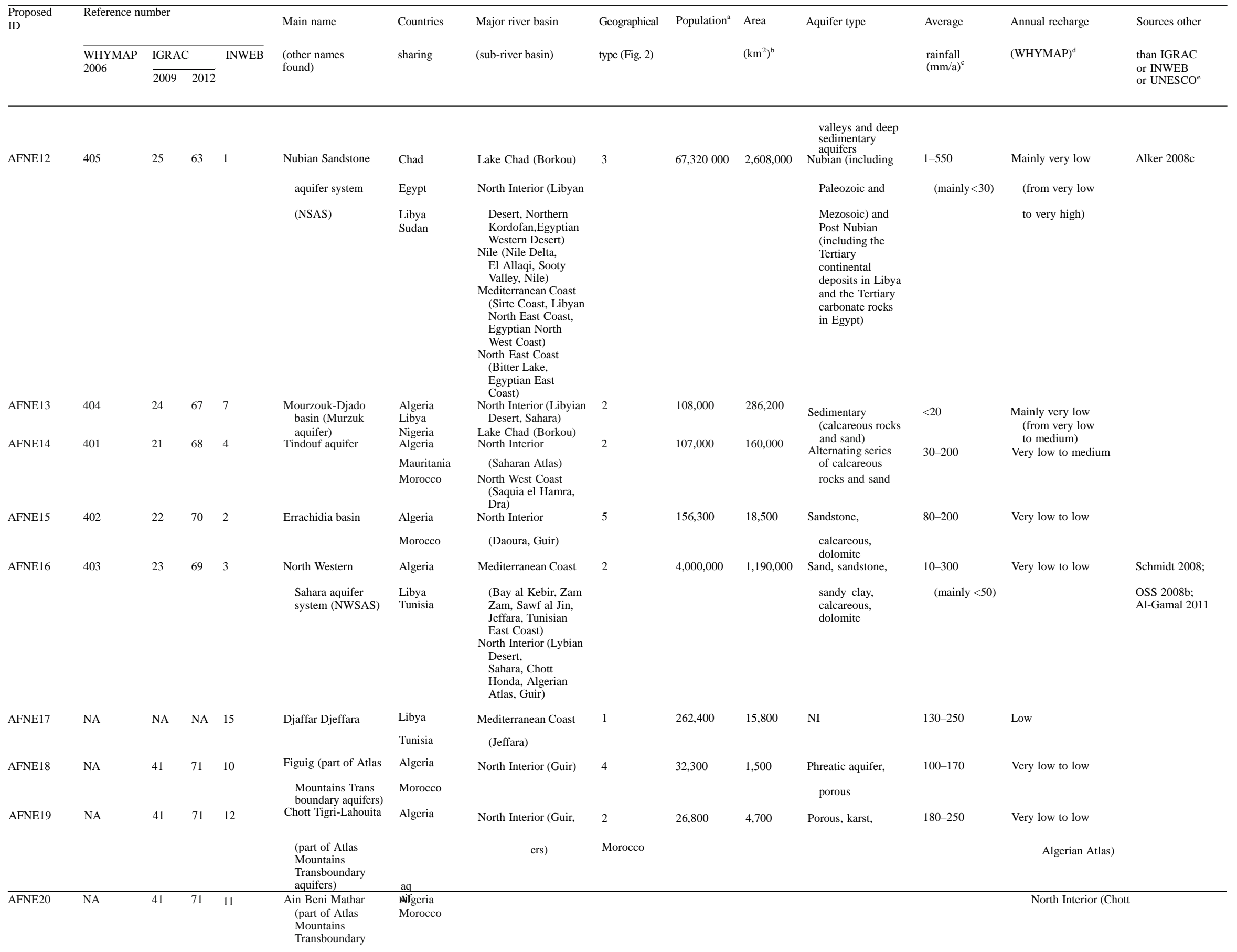


Table 4 (continued)

Chergui) Mediterranean Coast (Moulouya)

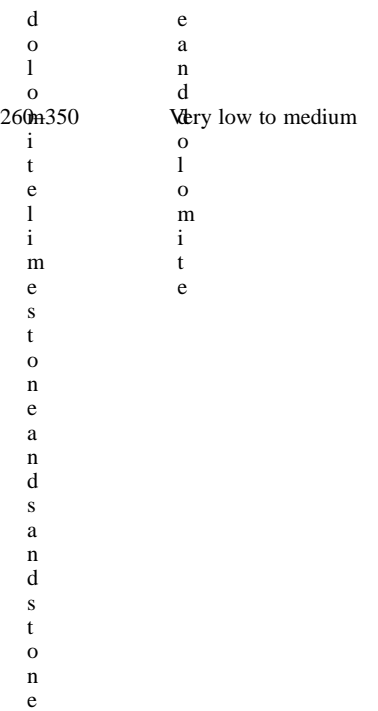

1

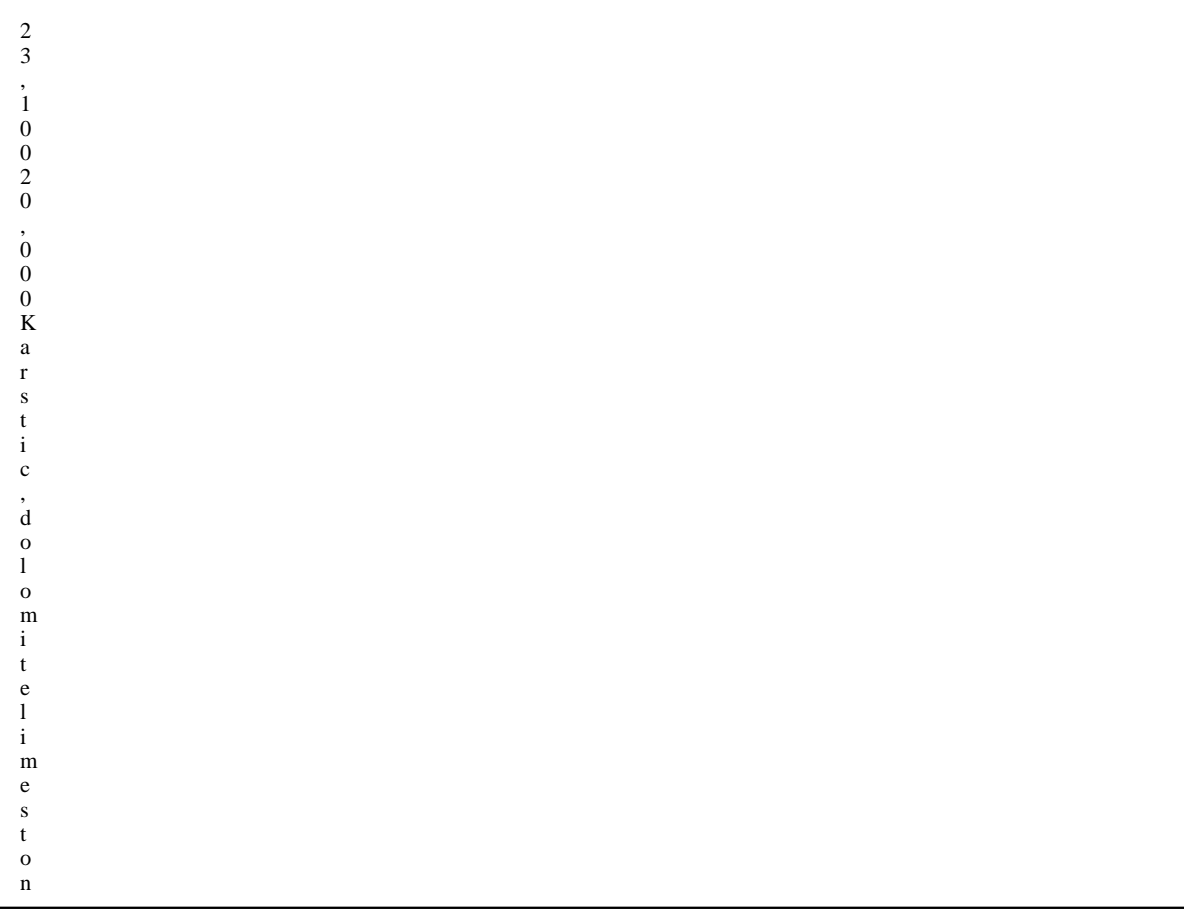


Table 4 (continued)

$41 \quad 71$

Angad (Angad- $\quad$ Algeria $\quad$ Mediterranean Coast

$\begin{array}{lrr}\text { Maghnia) (part of } & \text { Morocco } & \text { (Moulouya) } \\ \text { North Interior }\end{array}$

Atlas Mountains

Chott Chergui)

Quaternary

$350-450$

Very low to medium

Transboundary 
Table 4 (continued)

\begin{tabular}{|c|c|c|c|c|c|c|c|c|c|c|c|c|c|c|}
\hline \multirow[t]{3}{*}{$\begin{array}{l}\text { Proposed } \\
\text { ID }\end{array}$} & \multicolumn{4}{|c|}{ Reference number } & \multirow{3}{*}{$\begin{array}{l}\text { Main name } \\
\text { (other names } \\
\text { found) }\end{array}$} & \multirow{3}{*}{$\begin{array}{l}\text { Countries } \\
\text { sharing }\end{array}$} & \multirow{3}{*}{$\begin{array}{l}\text { Major river basin } \\
\text { (sub-river basin) }\end{array}$} & \multirow{3}{*}{$\begin{array}{l}\text { Geographical } \\
\text { type (Fig. 2) }\end{array}$} & \multirow[t]{3}{*}{ Popu ation ${ }^{\mathrm{a}}$} & \multirow{3}{*}{$\begin{array}{l}\text { Area } \\
\left(\mathrm{km}^{2}\right)^{\mathrm{b}}\end{array}$} & \multirow[t]{3}{*}{ Aquifer type } & \multirow{3}{*}{$\begin{array}{l}\text { Average } \\
\text { rainfall } \\
(\mathrm{mm} / \mathrm{a})^{\mathrm{c}}\end{array}$} & \multirow{3}{*}{$\begin{array}{l}\text { Annual recharge } \\
\text { (WHYMAP) }^{\mathrm{d}}\end{array}$} & \multirow{3}{*}{$\begin{array}{l}\text { Sources other } \\
\text { than IGRAC } \\
\text { or INWEB } \\
\text { or UNESCO }\end{array}$} \\
\hline & $\begin{array}{l}\text { WHYMAP } \\
2006\end{array}$ & IGRAC & & INWEB & & & & & & & & & & \\
\hline & & 2009 & 2012 & & & & & & & & & & & \\
\hline$\overline{\mathrm{AFNE} 22}$ & $\mathrm{NA}$ & $\overline{41}$ & 71 & 14 & $\begin{array}{l}\text { Jbel EI Hamra } \\
\text { (part of Atlas } \\
\text { Mountains } \\
\text { Transboundary } \\
\text { aquifers) }\end{array}$ & $\begin{array}{l}\text { Algeria } \\
\text { Morocco }\end{array}$ & $\begin{array}{r}\text { Mediterranean Coast } \\
\text { (Tafna, Moulouya) }\end{array}$ & $\overline{22}$ & 40,100 & 1,250 & Karstic & $\begin{array}{l}440-500 \\
\end{array}$ & Very low to low & \\
\hline AFNE23 & NA & 41 & 71 & 13 & $\begin{array}{l}\text { Triffa (part of Atlas } \\
\text { Mountains } \\
\text { Transboundary } \\
\text { aquifers) }\end{array}$ & $\begin{array}{l}\text { Algeria } \\
\text { Morocco }\end{array}$ & $\begin{array}{l}\text { Mediterranean Coast } \\
\text { (Tafna, Moulouya) }\end{array}$ & 2 & 920,000 & 13,100 & $\begin{array}{l}\text { Porous, } \\
\text { Villafranchian } \\
\text { and Quaternary }\end{array}$ & $370-450$ & Medium & \\
\hline AFS1 & 440 & 18 & 1 & $\mathrm{NA}$ & $\begin{array}{l}\text { Karoo Sedimentary } \\
\text { aquifer }\end{array}$ & $\begin{array}{l}\text { Lesotho } \\
\text { South Africa }\end{array}$ & $\begin{array}{l}\text { Orange basin (Orange, } \\
\text { Caledon, Vaal); } \\
\text { Indian Ocean Coast } \\
\text { (Thukela, Mgeni, } \\
\text { Mzimkulu, Groot } \\
\text { kei, Groot Vis) }\end{array}$ & 3 & $5,568,000$ & 166,000 & $\begin{array}{l}\text { Consolidated } \\
\text { sedimentary } \\
\text { rocks }\end{array}$ & $350-1,200$ & Very low to medium & \\
\hline AFS2 & 439 & 17 & 2 & NA & $\begin{array}{l}\text { Coastal Sedimentary } \\
\text { basin } 5 \text { (Gariep } \\
\text { aquifer) (Orange } \\
\text { River Coastal) }\end{array}$ & $\begin{array}{l}\text { Namibia } \\
\text { South Africa }\end{array}$ & $\begin{array}{l}\text { Orange basin } \\
\text { (Orange River); } \\
\text { South Atlantic Coast } \\
\text { (Groen) }\end{array}$ & 2 & 7,900 & 1,700 & $\begin{array}{l}\text { Quaternary and } \\
\text { consolidated } \\
\text { sedimentary } \\
\text { rocks }\end{array}$ & $45-55$ & Very low to medium & \\
\hline AFS3 & 438 & NA & 3 & $\mathrm{NA}$ & $\begin{array}{l}\text { Coastal Sedimentary } \\
\text { Basin } 6 \text { (Incomati/ } \\
\text { Maputo/Mbeluzi } \\
\text { basin) }\end{array}$ & $\begin{array}{l}\text { Mozambique } \\
\text { South Africa }\end{array}$ & $\begin{array}{l}\text { Indian Ocean Coast } \\
\text { (Mfolzi/Mkuze, } \\
\text { Maputo) }\end{array}$ & 2 & 548,000 & 11,700 & $\begin{array}{l}\text { Quaternary and } \\
\text { consolidated } \\
\text { sedimentary } \\
\text { rocks }\end{array}$ & $700-1,200$ & Medium to high & $\begin{array}{l}\text { Wellfield and } \\
\text { BGS } 2011\end{array}$ \\
\hline AFS4 & 438 & 19 & 4 & $\mathrm{NA}$ & $\begin{array}{l}\text { Rhyolite-Breccia } \\
\text { aquifer (Umbaluzi } \\
\text { basin; Maputo } \\
\text { Primary aquifer; } \\
\text { Incomati/Maputo/ } \\
\text { Umbaluzi basin) }\end{array}$ & $\begin{array}{l}\text { Mozambique } \\
\text { South Africa } \\
\text { Swaziland }\end{array}$ & $\begin{array}{l}\text { Indian Ocean Coast } \\
\text { (Black Umbeluzi, } \\
\text { Maputo, Incomati) }\end{array}$ & 5 & 206,000 & 5,500 & Volcanic/Quaternary & $600-850$ & Very low to medium & \\
\hline AFS5 & 434 & 13 & 5 & $\mathrm{NA}$ & $\begin{array}{l}\text { South West Kalahari/ } \\
\text { Karoo basin (SE } \\
\text { Kalahari/Karoo } \\
\text { basin; Stampriet// } \\
\text { Orange River; } \\
\text { encompasses } \\
\text { Nossop basin) }\end{array}$ & $\begin{array}{l}\text { Botswana } \\
\text { Namibia } \\
\text { South Africa }\end{array}$ & $\begin{array}{l}\text { Orange basin } \\
\text { (Nosob, Auob) }\end{array}$ & 4 & 15,500 & 85,000 & $\begin{array}{l}\text { Kalahari groups } \\
\text { aquifer and Karoo } \\
\text { supergroup } \\
\text { aquifers (the Auob } \\
\text { and Nossob } \\
\text { sandstone of the } \\
\text { Ecca subgroup in } \\
\text { the Karoo and } \\
\text { Kalahari } \\
\text { sequences) }\end{array}$ & $200-350$ & Very low to medium & $\begin{array}{l}\text { Alker 2008a; } \\
\text { ORASECOM } \\
2009 ; \\
\text { Wellfield and BGS } \\
2011\end{array}$ \\
\hline AFS6 & $\mathrm{NA}$ & NA & NA & $\mathrm{NA}$ & Ncojane aquifer & $\begin{array}{l}\text { Botswana } \\
\text { Namibia }\end{array}$ & $\begin{array}{l}\text { South Interior/ } \\
\text { Okavango (Okwa) } \\
\text { Orange basin } \\
\text { (Nosob, Molopo) }\end{array}$ & 5 & 2,300 & 10,300 & $\begin{array}{l}\text { Consolidated } \\
\text { sedimentary rocks } \\
\text { (Karoo and } \\
\text { Kalahari groups) }\end{array}$ & $300-350$ & Very low to medium & Rahube 2003 \\
\hline AFS7 & NA & NA & 6 & NA & $\begin{array}{l}\text { Khakhea/Bray } \\
\text { Dolomite (Tosca/ } \\
\text { Pomfret - }\end{array}$ & South Africa & Orange basin & 4 & $\begin{array}{r}57,000 \\
\mathrm{~V} \\
\mathrm{e}\end{array}$ & 30,000 & $\begin{array}{c}\text { Dolomite } \\
\text { gelegen Dolomite) }\end{array}$ & $300-450$ & Very low to medium & Turton et al. 2006 \\
\hline
\end{tabular}


Table 4 (continued)

Botswana

AFS8

435

14

$\mathrm{NA}$

Ramotswa

Dolomite basin

Botswana

South Afric

(Marico, KroKodil);

South Africa

Zimbabwe

(Olifants, Limpopo)

(encompasses

aquifer)

(a) basement rocks
Eriksson 1999;

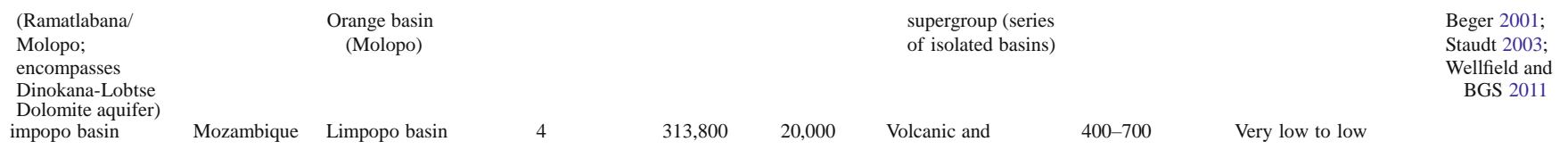


Table 4 (continued)

\begin{tabular}{|c|c|c|c|c|c|c|c|c|c|c|c|c|c|c|}
\hline \multirow[t]{3}{*}{$\begin{array}{l}\text { Proposed } \\
\text { ID }\end{array}$} & \multicolumn{4}{|c|}{ Reference number } & \multirow{3}{*}{$\begin{array}{l}\text { Main name } \\
\text { (other names } \\
\text { found) }\end{array}$} & \multirow{3}{*}{$\begin{array}{l}\text { Countries } \\
\text { sharing }\end{array}$} & \multirow{3}{*}{$\begin{array}{l}\text { Major river basin } \\
\text { (sub-river basin) }\end{array}$} & \multirow{3}{*}{$\begin{array}{l}\text { Geographical } \\
\text { type (Fig. 2) }\end{array}$} & \multirow[t]{3}{*}{ Popu ation ${ }^{\mathrm{a}}$} & \multirow{3}{*}{$\begin{array}{l}\text { Area } \\
\left(\mathrm{km}^{2}\right)^{\mathrm{b}}\end{array}$} & \multirow[t]{3}{*}{ Aquifer type } & \multirow{3}{*}{$\begin{array}{l}\text { Average } \\
\text { rainfall } \\
(\mathrm{mm} / \mathrm{a})^{\mathrm{c}}\end{array}$} & \multirow{3}{*}{$\begin{array}{l}\text { Annual recharge } \\
\text { (WHYMAP) }^{\mathrm{d}}\end{array}$} & \multirow{3}{*}{$\begin{array}{l}\text { Sources other } \\
\text { than IGRAC } \\
\text { or INWEB } \\
\text { or UNESCO }\end{array}$} \\
\hline & \multirow{2}{*}{$\begin{array}{l}\text { WHYMAP } \\
2006\end{array}$} & \multicolumn{2}{|c|}{ IGRAC } & \multirow[t]{2}{*}{ INWEB } & & & & & & & & & & \\
\hline & & 2009 & 2012 & & & & & & & & & & & \\
\hline \multirow[t]{2}{*}{$\mathrm{AES} 10$} & 436 & 15 & 2 & NA & Tuli Karoo Sub- & Botswana & Limpopo hasin & 4 & 70600 & 14330 & Volcanic and & & & \\
\hline & & & & & $\begin{array}{l}\text { Basin (Gaborone } \\
\text { To Shashe River; } \\
\text { encompasses } \\
\text { Motloutse Sand } \\
\text { River aquifer) }\end{array}$ & $\begin{array}{l}\text { South Africa } \\
\text { Zimbabwe }\end{array}$ & $\begin{array}{l}\text { (Limpopo, Sashe, } \\
\text { Motloutse) }\end{array}$ & & & & $\begin{array}{l}\text { basement rocks } \\
\text { (plus alluvial } \\
\text { along river) }\end{array}$ & $300-450$ & Very low to low & $\begin{array}{c}\text { Wellfield and } \\
\text { BGS } 2011\end{array}$ \\
\hline \multirow[t]{2}{*}{ AFS11 } & 430 & 9 & 10 & NA & Northern Kalahari/ & Angola & South Interior/ & 4 & 35,900 & 144,400 & Consolidated & $380-550$ & Very low to high & Stadtler et al. \\
\hline & & & & & $\begin{array}{l}\text { Karoo basin } \\
\text { (encompasses } \\
\text { Okavango aquifer } \\
\text { and Eiseb Graben) }\end{array}$ & $\begin{array}{l}\text { Botswana } \\
\text { Namibia } \\
\text { Zambia }\end{array}$ & $\begin{array}{l}\text { Okavango } \\
\text { (Okavango, Okwa, } \\
\text { Omuramba } \\
\text { Omatako) }\end{array}$ & & & & $\begin{array}{l}\text { sedimentary } \\
\text { rocks }\end{array}$ & & & 2005 \\
\hline \multirow[t]{2}{*}{ AFS12 } & NA & NA & 11 & NA & Save Alluvial aquifer & Mozambique & Indian Ocean Coast & 5 & 32,600 & 4,500 & Alluvial & $400-600$ & Very low to medium & Burgeap 1962 \\
\hline & & & & & & Zimbabwe & (Save, Runde, Buzi) & & & & & & & \\
\hline \multirow[t]{2}{*}{ AFS13 } & NA & 24 & 12 & NA & Eastern Kalahari/ & Botswana & South Interior/ & 4 & 54,300 & 39,600 & Upper Karoo & $400-600$ & Very low to medium & Wellfield and \\
\hline & & & & & $\begin{array}{l}\text { Karoo basin } \\
\text { (encompasses } \\
\text { Panda/ } \\
\text { Nyamandlovu } \\
\text { aquifer) }\end{array}$ & Zimbabwe & $\begin{array}{l}\text { Okavango (Botletli, } \\
\text { Okavango) }\end{array}$ & & & & Sandstone & & & BGS 2011 \\
\hline \multirow[t]{2}{*}{ AFS14 } & 429 & 20 & 13 & NA & Cuvelai and & Angola & South West Coast & 5 & $1,032,400$ & 202,000 & Consolidated & $300-900$ & Low to medium & Wellfield and \\
\hline & & & & & $\begin{array}{l}\text { Etosha basin } \\
\text { (encompasses } \\
\text { Ohangwena II } \\
\text { aquifer) }\end{array}$ & Namibia & $\begin{array}{l}\text { (Kunene) } \\
\text { South Interior/Cuvelai- } \\
\text { Etosha (Omuramba } \\
\text { Ovambo/Cuvelai- } \\
\text { Etosha) }\end{array}$ & & & & $\begin{array}{l}\text { sedimentary } \\
\text { rocks }\end{array}$ & & & BGS 2011 \\
\hline \multirow[t]{2}{*}{ AFS15 } & 431 & 10 & 14 & NA & Nata Karoo Sub- & Botswana & South Interior & 5 & 195,000 & 91,000 & Ecca sequence & $500-750$ & Very low to medium & \\
\hline & & & & & $\begin{array}{l}\text { Basin (Lower } \\
\text { Caprivi aquifer) }\end{array}$ & $\begin{array}{l}\text { Namibia } \\
\text { Zimbabwe }\end{array}$ & $\begin{array}{l}\text { (Okavango) } \\
\text { Zambezi basin } \\
\text { (Cuando, Zambezi, } \\
\text { Luanda) }\end{array}$ & & & & & & & \\
\hline \multirow[t]{2}{*}{ AFS16 } & 428 & 8 & 15 & NA & Coastal Sedimentary & Angola & South West Coast & 2 & 20 & 2,200 & Quaternary and & $100-150$ & Very low to medium & \\
\hline & & & & & $\begin{array}{l}\text { Basin } 4 \text { (Cunene } \\
\text { River Coastal) }\end{array}$ & Namibia & (Kunene) & & & & $\begin{array}{l}\text { consolidated } \\
\text { sedimentary rocks }\end{array}$ & & & \\
\hline \multirow[t]{2}{*}{ AFS17 } & 432 & 11 & 16 & NA & Medium Zambezi & Mozambique & Zambezi basin & 4 & 50,800 & 10,700 & Quaternary and & $720-780$ & Very low to medium & Wellfield and \\
\hline & & & & & $\begin{array}{l}\text { aquifer (Middle } \\
\text { Zambezi Rift } \\
\text { Upper Karoo } \\
\text { aquifer; } \\
\text { encompasses } \\
\text { Ponguwe basin) }\end{array}$ & $\begin{array}{l}\text { Zambia } \\
\text { Zimbabwe }\end{array}$ & $\begin{array}{l}\text { (Zambezi, Lake } \\
\text { Kariba, Nabuguyu, } \\
\text { Kafue) }\end{array}$ & & & & $\begin{array}{l}\text { consolidated } \\
\text { sedimentary rock } \\
\text { (lower and upper } \\
\text { Karoo Sandstones) }\end{array}$ & & & BGS 2011 \\
\hline AFS18 & 433 & 12 & 17 & NA & Shire Valley aquifer & $\begin{array}{l}\text { Malawi } \\
\text { Mozambique }\end{array}$ & Zambezi basin (Shire) & 4 & 527,000 & 6,200 & Tertiary/Quaternary & $780-900$ & Medium to very high & $\begin{array}{l}\text { Wellfield and } \\
\text { BGS } 2011\end{array}$ \\
\hline \multirow[t]{2}{*}{ AFS19 } & NA & NA & 18 & NA & Arangua Alluvial & Mozambique & Zambezi basin & 4 & 12,500 & 21,200 & Alluvial & $700-1,100$ & Very low to medium & \\
\hline & & & & & & Zambia & $\begin{array}{l}\text { (Mucanha, Zambezi, } \\
\text { Lusemfwa) }\end{array}$ & & & & & & & \\
\hline \multirow[t]{2}{*}{ AFS20 } & NA & 23 & 19 & NA & Sand and Gravel & Malawi & Zambezi basin (Rukuru, & 4 & $2,233,000$ & 25,300 & Unconsolidated & $800-1,200$ & Very low to very high & Wellfield and \\
\hline & & & & & aquifer & Zambia & $\begin{array}{l}\text { Owangawa, } \\
\text { Luangwa, Namitete, } \\
\text { Lilongwe, Capoche, } \\
\text { Kaombe) }\end{array}$ & & & & $\begin{array}{l}\text { intergranular } \\
\text { aquifer and } \\
\text { weathered } \\
\text { basement complex }\end{array}$ & & & BGS 2011 \\
\hline
\end{tabular}


Table 4 (continued)

AFS2

Coastal Sedimentary

Mozambique East Central Coast

794,000

23,000

Quaternary and

930-1,200

High

$\begin{array}{ll}\text { Lukuledi, Ruvuma, } & \text { consolidated } \\ \text { Montepuez/ } & \text { sedimentary rock }\end{array}$

Wellfield and

Tanzania (Lukuledi, Ruvuma,

Rovunma Coastal

BGS 2011 
Table 4 (continued)

\begin{tabular}{|c|c|c|c|c|c|c|c|c|c|c|c|c|c|c|}
\hline \multirow{3}{*}{$\begin{array}{l}\text { Proposed } \\
\text { ID }\end{array}$} & \multicolumn{4}{|c|}{ Reference number } & \multirow{3}{*}{$\begin{array}{l}\text { Main name } \\
\text { (other names } \\
\text { found) }\end{array}$} & \multirow{3}{*}{$\begin{array}{l}\text { Countries } \\
\text { sharing }\end{array}$} & \multirow{3}{*}{$\begin{array}{l}\text { Major river basin } \\
\text { (sub-river basin) }\end{array}$} & \multirow{3}{*}{$\begin{array}{l}\text { Geographical } \\
\text { type (Fig. 2) }\end{array}$} & \multirow[t]{3}{*}{ Popu ation ${ }^{a}$} & \multirow{3}{*}{$\begin{array}{l}\text { Area } \\
\left(\mathrm{km}^{2}\right)^{\mathrm{b}}\end{array}$} & \multirow[t]{3}{*}{ Aquifer type } & \multirow{3}{*}{$\begin{array}{l}\text { Average } \\
\text { rainfall } \\
(\mathrm{mm} / \mathrm{a})^{\mathrm{c}}\end{array}$} & \multirow{3}{*}{$\begin{array}{l}\text { Annual recharge } \\
\text { (WHYMAP) }^{\mathrm{d}}\end{array}$} & \multirow{3}{*}{$\begin{array}{l}\text { Sources other } \\
\text { than IGRAC } \\
\text { or INWEB } \\
\text { or UNESCO }\end{array}$} \\
\hline & $\begin{array}{l}\text { WHYMAP } \\
2006\end{array}$ & IGRAC & & INWEB & & & & & & & & & & \\
\hline & & 2009 & 2012 & & & & & & & & & & & \\
\hline AFS22 & 426 & 6 & 21 & NA & $\begin{array}{l}\text { Karoo-Sandstone } \\
\text { aquifer (Rovunma } \\
\text { basin; Tunduru/ } \\
\text { Maniamba basin) }\end{array}$ & $\begin{array}{l}\text { Mozambique } \\
\text { Tanzania }\end{array}$ & $\begin{array}{l}\text { East Central Coast } \\
\text { (Rufiji, Mantadu, } \\
\text { Mbwenkuru, } \\
\text { Ruvuma) } \\
\text { Zambezi basin } \\
\text { (Eastern catchment } \\
\text { Lake Nyasa) }\end{array}$ & 3 & 214,500 & 40,000 & $\begin{array}{l}\text { Consolidated } \\
\text { sedimentary rocks } \\
\text { (Karoo sandstone } \\
\text { that underlies } \\
\text { basalts) }\end{array}$ & $900-1,700$ & Medium to very high & $\begin{array}{c}\text { Wellfield and } \\
\text { BGS } 2011\end{array}$ \\
\hline AFS23 & NA & $\mathrm{NA}$ & 22 & NA & $\begin{array}{c}\text { Kalahari/Katangian } \\
\text { basin (Lualaba) }\end{array}$ & $\begin{array}{l}\text { DRC } \\
\text { Zambia }\end{array}$ & $\begin{array}{l}\text { Congo River basin } \\
\text { (Lake Mweru, } \\
\text { Lulaba) } \\
\text { Zambezi basin } \\
\text { (Lufwanyama, } \\
\text { Lunga) }\end{array}$ & 5 & $1,006,000$ & 15,600 & $\begin{array}{l}\text { Katangian sequence } \\
\text { (semi-consolidated } \\
\text { Aeolian sandstones } \\
\text { and gravels } \\
\text { deposited) and } \\
\text { Kalahari sequence } \\
\text { (consolidated } \\
\text { sedimentary rocks) }\end{array}$ & $1,200-1,300$ & High to very high & $\begin{array}{c}\text { Braune and } \\
\text { Xu } 2011\end{array}$ \\
\hline AFS24 & 422 & 5 & 23 & NA & $\begin{array}{l}\text { Congo Intra- } \\
\text { Cratonic (Congo/ } \\
\text { Zambesi basin; } \\
\text { Benguela Ridge } \\
\text { Watershed aquifer) }\end{array}$ & Angola DRC & $\begin{array}{l}\begin{array}{c}\text { South West Coast } \\
\text { (Cuanza) }\end{array} \\
\text { Congo River basin } \\
\text { (Kwango, Kasai, } \\
\text { Lulua) }\end{array}$ & 2 & $1,920,000$ & 317,200 & $\begin{array}{l}\text { Consolidated } \\
\text { sedimentary rocks } \\
\text { and alluvial }\end{array}$ & $1,200-1,650$ & High & $\begin{array}{c}\text { Wellfield and } \\
\text { BGS } 2011\end{array}$ \\
\hline AFS25 & NA & NA & 24 & NA & Weathered basement & $\begin{array}{l}\text { Malawi } \\
\text { Tanzania } \\
\text { Zambia }\end{array}$ & $\begin{array}{l}\text { Zambezi basin } \\
\text { (Luangwa, Rukuru, } \\
\text { Lake Nyasa) }\end{array}$ & 5 & 852,000 & 25,842 & NI & $900-2,000$ & Medium to very high & \\
\hline & & & & & & & $\begin{array}{l}\text { Congo River } \\
\text { (Lake Mweru) }\end{array}$ & & & & & & & \\
\hline AFS26 & NA & NA & 25 & NA & Karoo Carbonate & CAR & Congo River & 5 & $9,400,000$ & 941,100 & Limestone and & $1,000-1,800$ & High to very high & \\
\hline & & & & & & $\begin{array}{l}\text { Congo } \\
\text { South Sudan }\end{array}$ & $\begin{array}{l}\text { (Oubangui, Ouaka, } \\
\text { Kotto, Mbomou, } \\
\text { Chinko, Ouatra, } \\
\text { Mbomou, Congo, } \\
\text { Uele, Aruwimi, } \\
\text { Lulaba, Lomani, } \\
\text { Sankuru, Lulua) } \\
\text { Nile basin (Sue, Sopo, } \\
\text { Kwahr M'boloko) }\end{array}$ & & & & sandstone & & & \\
\hline AFS27 & NA & NA & 26 & NA & Tanganyika aquifer & Burundi & $\begin{array}{l}\text { Nile basin (Kagera) } \\
\text { Southern basins, }\end{array}$ & 5 & $11,940,000$ & 222,300 & Fractured basalt & $800-1,800$ & Very low to very high & Coster 1960 \\
\hline AFS28 & NA & 22 & 27 & NA & $\begin{array}{l}\text { Dolomitic aquifer } \\
\text { (Lower Congo } \\
\text { Precambrian } \\
\text { Dolomite aquifer) }\end{array}$ & $\begin{array}{l}\text { DRC } \\
\text { Tanyslaia } \\
\text { BRenda }\end{array}$ & 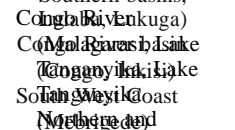 & 2 & 750,600 & 21,300 & $\begin{array}{l}\text { and granite } \\
\text { Karst weathered } \\
\text { dolomite }\end{array}$ & $1,100-1,450$ & High to very high & $\begin{array}{c}\text { Wellfield and } \\
\text { BGS } 2011\end{array}$ \\
\hline AFS29 & 421 & 4 & 28 & NA & $\begin{array}{l}\text { Coastal Sedimentary } \\
\text { Basin } 2 \text { (Congo } \\
\text { River Coastal) }\end{array}$ & $\begin{array}{l}\text { Angola } \\
\text { DRC }\end{array}$ & $\begin{array}{l}\text { Congo River basin } \\
\text { (Coast North/South } \\
\text { of Congo) }\end{array}$ & 2 & 34,000 & 2,250 & $\begin{array}{l}\text { Quaternary and } \\
\text { consolidated } \\
\text { sedimentary rocks }\end{array}$ & $800-1,000$ & Very low to high & $\begin{array}{c}\text { Wellfield and } \\
\text { BGS } 2011\end{array}$ \\
\hline AFS30 & NA & NA & 29 & NA & Cuvette Centale & $\begin{array}{l}\text { Congo } \\
\text { DRC }\end{array}$ & $\begin{array}{l}\text { Congo basin (Congo, } \\
\text { Oubangui, Sangha, } \\
\text { Likouala aux herbes, } \\
\text { Maringa, Kouyou, } \\
\text { Alima, Lefini, Inkisi, } \\
\text { Nsele, Bombo, } \\
\text { Lukenie, Kwango, } \\
\text { Kwa, Kasai, Lulua, } \\
\text { Sankuru, Lomani, }\end{array}$ & 2 & 14,000000 & 814,800 & Alluvial sandstones & $1,400-2,100$ & High to very high & Moukolo 1992 \\
\hline
\end{tabular}


Table 4 (continued)

\begin{tabular}{|c|c|c|c|c|c|c|c|c|c|c|c|c|c|c|}
\hline \multirow{3}{*}{$\begin{array}{l}\text { Proposed } \\
\text { ID }\end{array}$} & \multicolumn{4}{|c|}{ Reference number } & \multirow{3}{*}{$\begin{array}{l}\text { Main name } \\
\text { (other names } \\
\text { found) }\end{array}$} & \multirow{3}{*}{$\begin{array}{l}\text { Countries } \\
\text { sharing }\end{array}$} & \multirow{3}{*}{$\begin{array}{l}\text { Major river basin } \\
\text { (sub-river basin) }\end{array}$} & \multirow{3}{*}{$\begin{array}{l}\text { Geographical } \\
\text { type (Fig. 2) }\end{array}$} & \multirow[t]{3}{*}{ Population $^{\mathrm{a}}$} & \multirow{3}{*}{$\begin{array}{l}\text { Area } \\
\left(\mathrm{km}^{2}\right)^{\mathrm{b}}\end{array}$} & \multirow[t]{3}{*}{ Aquifer type } & \multirow{3}{*}{$\begin{array}{l}\text { Average } \\
\text { rainfall } \\
(\mathrm{mm} / \mathrm{a})^{\mathrm{c}}\end{array}$} & \multirow{3}{*}{$\begin{array}{l}\text { Annual recharge } \\
\text { (WHYMAP) }^{\mathrm{d}}\end{array}$} & \multirow{3}{*}{$\begin{array}{l}\text { Sources other } \\
\text { than IGRAC } \\
\text { or INWEB } \\
\text { or UNESCO }\end{array}$} \\
\hline & WHYMAP & IGRAC & & INWEB & & & & & & & & & & \\
\hline & & 2009 & 2012 & & & & & & & & & & & \\
\hline & & & & & & & $\begin{array}{l}\text { Momboya, Salomga, } \\
\text { Lomela, Tshuapa) } \\
\text { Central West Coast (Niari) }\end{array}$ & & & & & & & \\
\hline AFS31 & 425 & 3 & 31 & NA & $\begin{array}{l}\text { Coastal Sedimentary } \\
\text { Basin 1 (Umba } \\
\text { Coastal) }\end{array}$ & $\begin{array}{l}\text { Kenya } \\
\text { Tanzania }\end{array}$ & $\begin{array}{l}\text { East Central Coast } \\
\text { (Galana, Tana, } \\
\text { Kenyan South }\end{array}$ & 2 & $2,150,000$ & 16,800 & $\begin{array}{l}\text { Quaternary and } \\
\text { consolidated } \\
\text { sedimentary }\end{array}$ & $850-1,250$ & Medium to high & \\
\hline AFS32 & 424 & 2 & 32 & NA & Kilimanjero aquifer & $\begin{array}{l}\text { Kenya } \\
\text { Tanzania }\end{array}$ & $\begin{array}{l}\text { Coast, Umba) } \\
\text { East Central Coast } \\
\text { (Galana, Pangani) } \\
\text { Rift Valley (Lake } \\
\text { Natron) }\end{array}$ & 3 & $1,396,000$ & 14,600 & $\begin{array}{l}\text { rocks } \\
\text { Volcanic alluvium } \\
\text { (sand, gravel, clay } \\
\text { with calcareous } \\
\text { deposits with lava } \\
\text { and pyroclastic } \\
\text { volcanic rocks) }\end{array}$ & $600-1,600$ & Very low to medium & Grossmann 2008 \\
\hline \multirow[t]{2}{*}{ AFS33 } & 423 & 1 & 36 & $\mathrm{NA}$ & Kagera aquifer & Rwanda & Nile basin (Kagera) & 4 & 493,500 & 5,800 & Alluvial & $930-1,800$ & Very low to medium & \\
\hline & $\mathrm{NA}$ & 43 & 35 & $\mathrm{NA}$ & Mgahinga & $\begin{array}{l}\text { Tanzania } \\
\text { Uganda } \\
\text { DRC }\end{array}$ & Nile basin (Semliki, & 5 & $1,451,000$ & 4,400 & $\begin{array}{l}\text { unconsolidated } \\
\text { sand and gravels } \\
\text { Volcanic }\end{array}$ & $1,250-1,650$ & Very low to medium & \\
\hline AFS34 & & & & & & $\begin{array}{l}\text { Rwanda } \\
\text { Uganda }\end{array}$ & $\begin{array}{l}\text { Kagera) } \\
\text { Congo River basin } \\
\text { (Lulaba, Tanganyika } \\
\text { Northern basin) }\end{array}$ & & & & & & & \\
\hline \multirow[t]{2}{*}{ AFS35 } & NA & 44 & 37 & NA & Western Rift Valley & DRC & Nile basin (White Nile, & 4 & $1,151,000$ & 29,500 & Volcanic & $800-1,250$ & Very low to high & \\
\hline & & & & & Sediment & Uganda & $\begin{array}{l}\text { Semliki, Lake } \\
\text { Albert, Victoria } \\
\text { Nile) }\end{array}$ & & & & & & & \\
\hline \multirow[t]{2}{*}{ AFWC1 } & $\mathrm{NA}$ & NA & 30 & $\mathrm{NA}$ & NN & Congo & Central West Coast & 2 & 13,300 & 23,000 & NI & $1,400-1,750$ & Medium to very high & \\
\hline & & & & & & Gabon & (Mbia, Nyanga) & & & & & & & \\
\hline \multirow[t]{2}{*}{ AFWC2 } & $\mathrm{NA}$ & NA & 33 & $\mathrm{NA}$ & $\mathrm{NN}$ & Congo & Central West Coast & 3 & 48,500 & 7,100 & NI & $1,650-1,950$ & High to very high & \\
\hline & & & & & & Gabon & $\begin{array}{l}\text { (Ngounie/Ogooue, } \\
\text { Nyanga) }\end{array}$ & & & & & & & \\
\hline \multirow[t]{2}{*}{ AFWC3 } & $\mathrm{NA}$ & NA & 34 & $\mathrm{NA}$ & $\mathrm{NN}$ & Congo & Central West Coast & 2 & 41,000 & 23,500 & NI & $1,750-1,950$ & High to very high & \\
\hline & & & & & & Gabon & (Ogooue, Nyanga) & & & & & & & \\
\hline \multirow[t]{2}{*}{ AFWC4 } & NA & NA & 40 & $\mathrm{NA}$ & $\mathrm{NN}$ & Congo & Central West Coast & 4 & 1,700 & 19,600 & NI & $1,600-1,750$ & High to very high & \\
\hline & NA & NA & 41 & NA & $\mathrm{NN}$ & $\begin{array}{l}\text { Gabon } \\
\text { Cameroon }\end{array}$ & $\begin{array}{l}\text { (Ogooue:Ivindo and } \\
\text { lalara) } \\
\text { Central West Coast }\end{array}$ & 3 & 178,000 & 66,400 & NI & $1,550-1,650$ & High to very high & \\
\hline \multirow{2}{*}{ AFWC5 } & & & & & & $\begin{array}{l}\text { CAR } \\
\text { Gabon }\end{array}$ & $\begin{array}{l}\text { (Nyong, Ivindo/ } \\
\text { Ogooue) }\end{array}$ & & & & & & & \\
\hline & & & & & & & $\begin{array}{l}\text { Congo River basin } \\
\text { (Boumba, Kadei) }\end{array}$ & & & & & & & \\
\hline \multirow[t]{2}{*}{ AFWC6 } & $\mathrm{NA}$ & NA & 42 & $\mathrm{NA}$ & Rio Delrey & Cameroon & Central West Coast & 3 & $3,300,000$ & 24,000 & Upper Miocene & $2,500-3,130$ & Very high & \\
\hline & & & & & & Nigeria & $\begin{array}{l}\text { (Cross, Andokat/ } \\
\text { Akpa, Mungo) }\end{array}$ & & & & to Quaternary & & & \\
\hline AFWC7 & 414 & 34 & 48 & $\mathrm{NA}$ & Keta basin (Keita) & $\begin{array}{l}\text { Benin } \\
\text { Nigeria } \\
\text { Togo }\end{array}$ & $\begin{array}{l}\text { West Coast (Volta, } \\
\text { Mono, Kouffo, } \\
\text { Oueme, Yewa, } \\
\text { Ogun, Oshun, Osse) }\end{array}$ & 3 & 16,896000 & 55,400 & $\begin{array}{l}\text { Quaternary } \\
\text { (sand, silt, clay) }\end{array}$ & $950-2,450$ & High to very high & \\
\hline \multirow[t]{2}{*}{ AFWC8 } & 413 & 33 & 47 & $\mathrm{NA}$ & Tano basin & Cote d'Ivoire & West Coast (Davo, & 3 & 4.740 .000 & 43.000 & Quaternary Terminal & $1.300-1.930$ & High to very high & \\
\hline & & & & & & Ghana & $\begin{array}{l}\text { Bandama, Agneby, } \\
\text { Komoe, Bia, Tano) }\end{array}$ & & & & $\begin{array}{l}\text { Continental and } \\
\text { Maestrichtien } \\
\text { aquifer }\end{array}$ & & & \\
\hline AFWC9 & $\mathrm{NA}$ & NA & 49 & $\mathrm{NA}$ & $\mathrm{NN}$ & $\begin{array}{l}\text { Cote d'Ivoire } \\
\text { Guinea } \\
\text { Liberia }\end{array}$ & $\begin{array}{l}\text { West Coast (Saint } \\
\text { Paul, Saint John, } \\
\text { Cavalla, Cesta. }\end{array}$ & 6 & $2,370,000$ & 47,300 & NI & $1,400-2,050$ & High to very high & \\
\hline
\end{tabular}


Table 4 (continued)

Sassandra) 
Table 4 (continued)

\begin{tabular}{|c|c|c|c|c|c|c|c|c|c|c|c|c|c|c|}
\hline \multirow{3}{*}{$\begin{array}{l}\text { Proposed } \\
\text { ID }\end{array}$} & \multicolumn{4}{|c|}{ Reference number } & \multirow{3}{*}{$\begin{array}{l}\text { Main name } \\
\text { (other names } \\
\text { found) }\end{array}$} & \multirow{3}{*}{$\begin{array}{l}\text { Countries } \\
\text { sharing }\end{array}$} & \multirow{3}{*}{$\begin{array}{l}\text { Major river basin } \\
\text { (sub-river basin) }\end{array}$} & \multirow{3}{*}{$\begin{array}{l}\text { Geographical } \\
\text { type (Fig. 2) }\end{array}$} & \multirow[t]{3}{*}{ Population $^{\mathrm{a}}$} & \multirow{3}{*}{$\begin{array}{l}\text { Area } \\
\left(\mathrm{km}^{2}\right)^{\mathrm{b}}\end{array}$} & \multirow[t]{3}{*}{ Aquifer type } & \multirow{3}{*}{$\begin{array}{l}\text { Average } \\
\text { rainfall } \\
(\mathrm{mm} / \mathrm{a})^{c}\end{array}$} & \multirow{3}{*}{$\begin{array}{l}\text { Annual recharge } \\
\text { (WHYMAP) }^{\mathrm{d}}\end{array}$} & \multirow{3}{*}{$\begin{array}{l}\text { Sources other } \\
\text { than IGRAC } \\
\text { or INWEB } \\
\text { or UNESCO }\end{array}$} \\
\hline & \multirow[t]{2}{*}{$\begin{array}{l}\text { WHYMAP } \\
2006\end{array}$} & \multicolumn{2}{|c|}{ IGRAC } & \multirow[t]{2}{*}{ INWEB } & & & & & & & & & & \\
\hline & & 2009 & 2012 & & & & & & & & & & & \\
\hline \multirow[t]{2}{*}{ AFWC11 } & NA & $\mathrm{NA}$ & 51 & $\mathrm{NA}$ & Garoua - Chari & Cameroon & Niger River & 4 & $1,870,000$ & 38,400 & Sandstone - clay & $950-1,400$ & High to very high & \\
\hline & & & & & & Nigeria & (Benue, Faro) & & & & & & & \\
\hline \multirow[t]{4}{*}{ AFWC12 } & NA & NA & 50 & NA & $\mathrm{NN}$ & Cameroon & Lake Chad (Logone, & 4 & 716,000 & 155,400 & Sedimentary & $700-1,600$ & High to very high & \\
\hline & & & & & & CAR & Ouham, Chari, Barh & & & & (Quaternary & & & \\
\hline & & & & & & Chad & Keita, Oulou, Bahr & & & & and Tertiary) & & & \\
\hline & & & & & & & & & & & & & & \\
\hline \multirow[t]{2}{*}{ AFWC13 } & NA & 47 & 62 & NA & Disa & Chad & Lake Chad (Bahr & 4 & 74,300 & 1,500 & Sandstone & $500-550$ & Very low to medium & \\
\hline & & & & & & Sudan & Azum) & & & & & & & \\
\hline \multirow[t]{10}{*}{ AFWC14 } & 412 & 32 & 52 & NA & Lake Chad & CAR & Lake Chad (Borkou, & 5 & $22,419,100$ & $1,300,500$ & Sedimentary aquifer & $40-1,400$ & Very low to high & Alker 2008c \\
\hline & & & & & (encompasses & Cameroon & Dilia, Komadugu & & & & with three main & & & \\
\hline & & & & & Grand Yaéré & Chad & Yobe, Koramas, & & & & aquifers: the & & & \\
\hline & & & & & Plains aquifer & Niger & Hadedja, Jamaare, & & & & Upper Quaternary, & & & \\
\hline & & & & & and Bilma- & Nigeria & Komadugu Gana, & & & & the lower Pliocene & & & \\
\hline & & & & & & & Chitati, Lake Chad, & & & & $\begin{array}{l}\text { and the Terminal } \\
\text { Continental (TC; }\end{array}$ & & & \\
\hline & & & & & & & $\begin{array}{l}\text { Dagana, Fitri, Charı, } \\
\text { Bahr Keita, Ouham, }\end{array}$ & & & & Oligocene- & & & \\
\hline & & & & & & & Logone, Yedseram) & & & & Miocene) & & & \\
\hline & & & & & & & Niger River & & & & & & & \\
\hline & & & & & & & $\begin{array}{l}\text { (Gongola, Benue, } \\
\text { Faro, Mayo kebi) }\end{array}$ & & & & & & & \\
\hline \multirow[t]{7}{*}{ AFWC15 } & 411 & 31 & 56 & 6 & Irhazer-Iullemeden & Algeria & Lake Chad (Dilia, & 5 & $12,888,600$ & 545,400 & Group of & $80-900$ & Very low to very high & OSS 2008a \\
\hline & & & & & & Mali & Kormaras) & & & & sedimentary & & & \\
\hline & & & & & & Niger & Niger River & & & & deposits & & & \\
\hline & & & & & & Nigeria & (Tilemsi, Niger, & & & & containing two & & & \\
\hline & & & & & & & $\begin{array}{l}\text { Dallol Bosso, } \\
\text { Dallol Maouri, }\end{array}$ & & & & $\begin{array}{l}\text { main aquifers: } \\
\text { Intercalary }\end{array}$ & & & \\
\hline & & & & & & & $\begin{array}{l}\text { Tarka, Sotoko, } \\
\text { Tok }\end{array}$ & & & & Continental (IC) & & & \\
\hline & & & & & & & $\begin{array}{l}\text { N'Kaba, Bunsuru, } \\
\text { Zamfara, Gulbinka) }\end{array}$ & & & & and Terminal & & & \\
\hline AFWC16 & $\mathrm{NA}$ & NA & 60 & NA & $\mathrm{NN}$ & Burkina & Niger basin (Gorouol, & 4 & 333,000 & 36,500 & NI & $250-600$ & Very low to medium & \\
\hline & & & & & & & Niger, Faga) & & & & & & & \\
\hline & & & & & & $\begin{array}{l}\text { Mali } \\
\text { Niger }\end{array}$ & & & & & & & & \\
\hline AFWC17 & 410 & 30 & 57 & $\mathrm{NA}$ & Liptako-Gourma & Burkina & West Coast $/$ Volta & 5 & $7,758,300$ & 159,500 & Fractured & $400-900$ & Verv low to high & \\
\hline & & & & & aquifer & Faso & (Sourou, Nakambe, & & & & metamorphic & & & \\
\hline & & & & & $\begin{array}{l}\text { (encompasses } \\
\text { Gondo Plain) }\end{array}$ & & $\begin{array}{l}\text { Mouhoun, Oti) } \\
\text { Niger River }\end{array}$ & & & & & & & \\
\hline & & & & & & & (Gorouol, Faga, & & & & & & & \\
\hline & & & & & & & Niger) & & & & & & & \\
\hline AFWC18 & NA & $\mathrm{NA}$ & 55 & NA & NN & $\begin{array}{l}\text { Guinea } \\
\text { Mai }\end{array}$ & $\begin{array}{l}\text { Niger basin (Tinkisso, } \\
\text { Mafou, Niger, }\end{array}$ & 6 & $4,250,000$ & 185,500 & $\begin{array}{l}\text { Birrimien (schist } \\
\text { and sandstone) }\end{array}$ & $850-1,650$ & Very low to very high & \\
\hline & & & & & & Senegal & Sankarani, Baoule) & & & & & & & \\
\hline & & & & & & & $\begin{array}{l}\text { Senegal basin } \\
\text { (Bakoy, Bafing }\end{array}$ & & & & & & & \\
\hline & & & & & & & $\begin{array}{l}\text { (Bakoy, Bating, } \\
\text { Faleme) }\end{array}$ & & & & & & & \\
\hline & & & & & & & $\begin{array}{l}\text { West Coast } \\
\text { (Gambia, Corubal) }\end{array}$ & & & & & & & \\
\hline AFWC19 & 406 & 26 & 58 & $\mathrm{NA}$ & Senegalo- & Gambia. & North West Coast & 3 & $11,930,000$ & 331,450 & Maastrichtien & $20-1,850$ & Very low to very high & \\
\hline & & & & & Mauritanian & Guinea- & (Central Mauritania, & & & & (multilayer & & & \\
\hline
\end{tabular}


Table 4 (continued)

basin

Bissau
Mauritania

Adrar Sotuf)
Senegal River

(Senegal,

Katchi, Fer

West Coast

(Saloum, Gambia,

several aquiferous

system from
Cretaceous

Superior to the

Quaternary) 


\section{References}

Abiye TA (2010) Overview of the transboundary aquifers in East Africa. J African Earth Sci 58:684-691

African Ministers' Council on Water (AMCOW) and African Network of Basin Organisations (ANBO) (2007) Source book on Africa's river and lake basin organisations, vol 1. ANBO, Paris, $86 \mathrm{pp}$

Al-Gamal SA (2011) An assessment of recharge possibility to North-Western Sahara Aquifer System (NWSAS) using environmental isotopes. J Hydrol 398(3-4):184-190

Alker M (2008a) The Stampriet Artesian Basin. In: Scheumann W, Herrfahrdt-Pähle E (eds) Conceptualizing cooperation on Africa's transboundary groundwater resources. Deutsches Institut für Entwicklungspolitik, Bonn, Germany, pp 165-202

Alker M (2008b) The Nubian Sandstone Aquifer System. In: Scheumann W, Herrfahrdt-Pähle E (eds) Conceptualizing cooperation on Africa's transboundary groundwater resources. Deutsches Institut für Entwicklungspolitik, Bonn, Germany, pp 231-274

Alker M (2008c) The Lake Chad, a case study for the research project "Transboundary groundwater management in Africa". In: Scheumann W, Herrfahrdt-Pähle E (eds) Conceptualizing cooperation on Africa's transboundary groundwater resources. Deutsches Institut für Entwicklungspolitik, Bonn, Germany, pp 125-164

Amani A (2011) Gestion des aquifères transfrontaliers en Afrique de l'Ouest et du Centre [Newly identified and old transboundary aquifers in Africa, Atelier région ]. UNESCO ISARM-IHP, Paris

Aureli A, Eckstein G (2011) Strengthening cooperation on transboundary groundwater resources. Water Int 36(5):549-556

Barberis J (1991) The international law of the hydrologic cycle: the development of international law of transboundary groundwater. Nat Resour J 31:167-186

Becht RF, Mwango F, Muno FA (2006) Groundwater links between Kenyan rift valley lakes. In: Odada EO et al (eds) Proceedings of the 11th World Lakes Conference, vol 2, Nairobi, Kenya, 31 Oct.-4 Nov. 2005, International Lake Environment Committee (ILEC), Oroshimo-cho Kusatsu-shi, Japan, pp 7-14

Beger K (2001) Environmental hydrogeology of Lobatse. Report by the Environmental Geology Division. Dept. of Geological Survey, Lobatse, Botswana

Braune E, Xu Y (2011) Transboundary aquifer utilization and management in Southern Africa: water - a shared responsibility, ISARM-SADC, Position paper for the UNESCO Cluster Office, Harare, Zimbabwe, 53 pp

Burchi S, Mechlem K (2005) Groundwater in international law: compilation of treaties and other legal instruments. FAO legislative study no. 86, UNESCO-FAO, Rome $566 \mathrm{pp}$

BURGEAP (Bureaux d'Etudes de Geologie Appliquee et d'Hydrologie Souterraine) (1962) Hydrogeologie du Sud du Save [Hydrogeology of southern Save], Serie de Geologica e Minas - Memorias e Comunicacoes, Bulletin no. 30, BURGEAP, Neuilly, France

Cascão A (2010) Changing nature of bargaining power in the hydropolitical relations in the Nile River Basin, chap 13.1. In: Earle A, Jägerskog A, Öjendal J (eds) Transboundary water management: principles and practice. Earthscan, London, pp 189-194

Catuneanu O, Eriksson P (1999) The sequence stratigraphic concept and the Precambrian rock record: an example from the 2.7-2.1 Ga Transvaal Supergroup, Kaapvaal craton. Precambrian Res 97:215-251

Christelis G, Hunger G, Mulele O, Mangisi N, Mannathoko I, van Wyk E, Braune E, Heyns P (2010) Towards transboundary aquifer management in Southern Africa. http://www.siagua.org/ sites/default/files/documentos/documentos/sur_africa.pdf. Accessed 16 April 2013

Clifton C, Evans R, Hayes S, Hirji R, Puz G, Pizarro C (2010) Water and climate change: impacts on groundwater resources and adaptation options. WB working note no. 25, World Bank, Washington, DC

Cobbing JE, Hobbs PJ, Meyer R, Davies J (2008) A critical overview of transboundary aquifers shared by South Africa. Hydrogeol J 16:1207-1214. doi:10.1007/s10040-008-0285-2 
Colvin C, le Maitre D, Saayman I, Hughes S (2007) Aquifer dependent ecosystems in key hydrogeological typesettings in South Africa. WRC report no. TT 301/07, Water Research Commission, Pretoria, South Africa, $74 \mathrm{pp}$

Conca K, Fenshi W, Ciqi M (2006) Global regime formation or complex institution building? The principled content of international river agreements. Int Stud Q 50(2):263-285

Cooley H, Christian-Smith J, Gleick PH, Allen L, Cohen M (2009) Understanding and reducing the risks of climate change for transboundary waters. Pacific Institute in cooperation with UNEP, New York, 38 pp

Coster FM (1960) Underground water in Lake Tanganyika, Department of Water Resources and Irrigation of Tanzania. www.sadcgwarchive.net. Accessed on 16 April 2013

Davies J, Robins NS, Farr J, Sorensen J, Beetlestone P, Cobbing JE (2012) Identifying transboundary aquifers in need of international resource management in the Southern African Development Community region. Hydrogeol J. doi:10.1007/ s10040-012-0903-x

Dellapenna JW (2011) The customary law applicable to internationally shared groundwater. Water Int 36(5):584-594. doi:10.1080/02508060.2011.599025

Eckstein GE (2011) Managing buried treasure across frontiers: the international Law of Transboundary Aquifers. Water Int 36(5):573-583

Eckstein Y, Eckstein GE (2003a) Ground water resources and international law in the Middle East peace process. Water Int 28(2):154-161

Eckstein G, Eckstein Y (2003b) A hydrogeological approach to transboundary ground water resources and international law. Am Univ Int Law Rev 19:201-258

Giordano M, Drieschova A, Duncan J, Sano Y, De Stefano L, Wolf A (2013) A review of the evolution and state of transboundary freshwater treaties. Int Environ Agreements. doi:10.1007/s10784013-9211-8

Gleeson T, Manning AH (2008) Regional groundwater flow in mountainous terrain: three-dimensional simulations of topographic and hydrogeologic controls. Water Resour Res 44:W10403. doi:10.1029/2008WR006848

Global Environmental Facility (GEF) (2012) Contributing to Global Security. GEF Action on Water, Environment and Sustainable Livelihoods, GEF, Washington, DC, $52 \mathrm{pp}$

Global Water Partnership (GWP) (2013) International law: facilitating transboundary water cooperation. TEC Background Papers, no. 17, GWP, Stockholm, 85 pp

Granit J (2010) Identifying business models for transboundary river basin institutions, chap 10. In: Earle A, Jägerskog A, Öjendal J (eds) Transboundary water management: principles and practice. Earthscan, London, pp 143-155

Grossmann M (2008) The Kilimanjaro Aquifer: a case study for the research project "Transboundary groundwater management in Africa"-conceptualizing cooperation on Africa's transboundary groundwater resources. DIE studies, DIE, Bonn, Germany, pp 87124

Hilaire-Marcel C, Casanova J (1987) Isotopic hydrology and paleohydrology of the Magadi (Kenya) - Natron (Tanzania) basin during the late Quarternary. Paleogeogr Paleoclimatol Paleoecol 58:155-181

Huneau F, Dakoure D, Celle-Jeanton H, Vitvar T, Ito M, Traore S, Compaore NF, Jirakova H, Le Coustumer P (2011) Flow pattern and residence time of groundwater within the south-eastern Taoudeni sedimentary basin (Burkina Faso, Mali). J Hydrol 409(1-2):423-439

International Groundwater Resources Assessment Centre (IGRAC) (2009) Transboundary aquifers of the world: update 2009. Special Edition for 5th World Water Forum, Istanbul, Turkey, March 2009. http://www.un-igrac.org/publications/323. Accessed 16 April 2013

International Groundwater Resources Assessment Centre (IGRAC) (2012a) Transboundary aquifers of the world: update 2012. Special Edition for 6th World Water Forum, Marseille, France, March 2012. http://www.un-igrac.org/publications/456. Accessed 16 April 2013
International Groundwater Resources Assessment Centre (IGRAC) (2012b) Database. http://ggmn.e-id.nl/ggmn/GlobalOverview.html. Accessed 16 April 2013

International Network of Water-Environment Centres for the Balkans (INWEB) (2012) Shared aquifers in N. Africa database. http:// www.inweb.gr/index.php?Itemid=201. Accessed 16 April 2013

International Water Law Project (2012) The future of Africa's water security: archive for May 2012. http://www.internationalwaterlaw.org/ blog/2012/05/. Accessed 16 April 2013

International Water Law Project (2013) Status of the Watercourse Convention. http://www.internationalwaterlaw.org/documents/ intldocs/watercourse_status.html. Accessed 16 April 2013

Jarvis WT (2006) Transboundary groundwater: geopolitical consequences, commons sense, and the law of the hidden sea. $\mathrm{PhD}$ Thesis, Oregon State University, USA, $164 \mathrm{pp}$

Jarvis WT (2011) Unitization: a lesson in collective action from the oil industry for aquifer governance. Water Int 36(5):619-630. doi:10.1080/02508060.2011.598656

Jarvis T, Giordano M, Puri S, Matsumoto K, Wolf A (2005) Transboundary aquifers: do international borders serve as positive or negative flow boundaries? Ground Water 43(5):764-770. doi:10.1111/j.1745-6584.2005.00069.x

Kashaigili JJ (2010) Assessment of groundwater availability and its current and potential use and impacts in Tanzania. Country report. Groundwater in sub-Saharan Africa: implication for food security and livelihoods. International Water Management Institute, Colombo, Sri Lanke

Krhoda GO (1989) Groundwater assessment in sedimentary basins of eastern Kenya, Africa, IAHS Publ. no. 182, IAHS, Wallingford, UK, $198 \mathrm{pp}$

Linton J, Brooks DB (2011) Governance of transboundary aquifers: new challenges and new opportunities. Water Int 36(5):606618. doi:10.1080/02508060.2011.599312

MacDonald A, Bonsor H, Dochartaigh B, Taylor R (2012) Quantitative maps of groundwater resources in Africa. Environ Res Lett 7. doi:10.1088/1748-9326/7/2/024009

Marsala P, El Sayed M, Sultan M, Wahr J, Milewski A, Becker R, Welton B, Balekai R (2009) Integration of GRACE data with inferences from traditional datasets for a better understanding of the time-dependent water storage variability in large-scale aquifers: case studies from Africa. Paper no. 227-1, Geological Society of America, Boulder, $\mathrm{CO}$, Abstracts with programs

McCaffrey SC (2011) The International Law Commission's flawed Draft Articles on the Law of Transboundary Aquifers: the way forward. Water Int 36(5):566-572. doi:10.1080/02508060.2011.597094

Moukolo N (1992) Current state of hydrogeological knowledge in Congo Brazzaville. Hydrogéologie 1-2:47-58

Mumma A, Lane M, Kairu E, Tuinhof A, Hirji R (2011) Kenya groundwater governance: case study. Water Papers June 2011. http://water.worldbank.org/sites/water.worldbank.org/files/ GWGovernanceKenya.pdf. Accessed 16 April 2013

Mwango FK, Muhangú BC, Juma CO, Githae IT (2002) Groundwater resources in Kenya. Proceedings of the international workshop, Tripoli, Libya, 2-4 June 2002

Mwango FK, Muhangú BC, Juma CO, Githae IT (2004) Groundwater resources in Kenya. In: Managing shared aquifer resources in Africa. ISARM-Africa, Proceedings of the international workshop, Tripoli, Libya, 2-4 June 2002. IHP-VI, Series on Groundwater no. 8, UNESCO, Paris, pp 93-100

New Partnership for Africa's Development (NEPAD), African Union (AU), and African Development Bank (AfDB) (2011) Study on Programme for Infrastructure Development in Africa (PIDA): Phase I - transboundary water management (TWRM) sector, NEPAD, Johannesburg, South Africa, $32 \mathrm{pp}$

Öjendal J, Earle A, Jägerskog A (2010) Towards a conceptual framework for transboundary water management, chap 14. In: Earle A, Jägerskog A, Öjendal J (eds) Transboundary water management: principles and practice. Earthscan, London, pp 237-248

ORASECOM (2009) Groundwater review of the Molopo-Nossob basin for rural communities including assessment of national databases at the sub-basin level for possible future integration. Final report 2009, ORASECOM, Gauteng, South Africa 
OSS (2008a) Iullemeden Aquifer System (Mali, Niger, Nigeria): concerted management of shared water resources of a Sahelian transboundary aquifer. Synthesys Collection no. 2, OSS, Tunis, 33 pp OSS (2008b) The North-western Sahara Aquifer System (Algeria, Tunisia, Libya): joint management transborder water basin. Synthesis Collection No 1, OSS, Tunis, 48 pp

Owen R (2012) Groundwater needs assessment. Limpopo Basin Commission, LIMCOM. http://www.splash-era.net/downloads/ groundwater/2_LIMCOM_final_report.pdf. Accessed 16 April 2013

Puri S, Aureli A (2005) Transboundary aquifers: a global program to assess, evaluate and develop policy. Ground Water 43(5):661-668

Puri S, Aureli A (2009) Atlas of transboundary aquifers: global maps, regional cooperation and local inventories. ISARM Program, UNESCO-IHP, Paris

Rahube TB (2003) Recharge and groundwater resources evaluation of Lokalane-Ncojane Basin (Botswana) using numerical modelling. MSc Thesis, International Institute for Geo-information Science and Earth Observation, Enschede, The Netherlands

Sanchez N (2011) Legal definitions of 'groundwater' and 'aquifer'. http://www.nadiasanchez.com/2011/10/legal-definitions-ofgroundwater-and.html. Accessed on 16 April 2013

Saradeth S, Dodo AK, Latrech D (2010) Earth observation in support of management of internationally shared groundwater resources in Africa: the AQUIFER project. In: Application of satellite remote sensing to support water resources management in Africa: results from the TIGER Initiative. Technical Documents in Hydrology, no. 85, UNECO-IHP, Paris, pp 1-14

Scheumann W, Alker M (2009) Cooperation on Africa's transboundary aquifers: conceptual ideas. Hydrol Sci J 54(4):793-802

Scheumann W, Herrfahrdt-Pähle E (2008) Conceptualizing cooperation on Africa's transboundary groundwater resources. Deutsches Institut für Entwicklungspolitik, Bonn, Germany 394 pp

Schmeier S (2010) Effective governance of transboundary aquifers through institutions: lessons learned from river basin organizations. Paper prepared for the International Conference "Transboundary Aquifers: Challenges and New Directions", UNESCO, ISARM, Paris, 6-8 Dec. 2010

Schmidt O (2008) The North-West Sahara Aquifer System, a case study for the research project "Transboundary groundwater management in Africa". In: Conceptualizing cooperation on Africa's transboundary groundwater resources. Deutsches Institut für Entwicklungspolitik, Bonn, Germany, pp 203-230

Southern African Development Community (SADC) - WSCU (Water Sector Coordination Unit) (2001) Guidelines for the groundwater development in the SADC region. Report no. 2, SADC, Gaborone, Botswana, $181 \mathrm{pp}$

Siemon B, Roettger B, Pielawa J (2005) Interpretation of the helicopter-borne groundwater survey data of the eastern Caprivi area. German-Namibian Groundwater Exploration Project "Investigation of Groundwater Resources and AirborneGeophysical Investigation of Selected Mineral Targets in Namibia", vol II, GW3, BRG, Hannover, Germany

Southern African Development Community (SADC) (2011) Regional strategic action plan on integrated water resources development and management. (2011-2015) RSAP III. Watering life, together, forever. SADC, Gabrone, Botswana, $56 \mathrm{pp}$

Southern African Development Community (SADC) (1995) Protocol on shared watercourses in the Southern African Development Community. http://www.internationalwaterlaw.org/documents/ regionaldocs/sadc1.html. Accessed on 29 April 2013

Southern African Development Community) (SADC) (2000) Revised protocol on shared watercourses in the Southern African Development Community. http://www.sadc.int/files/ 3413/6698/6218/Revised_Protocol_on_Shared_Watercourses_

2000_-_English.pdf. Accessed 29 April 2013

Stadtler C, Margane A, Schildknecht F, Uwe Schäffer U, Wrabel J (2005) Investigation of the groundwater resources in the Eiseb Graben in Namibia with TEM Soundings. In: Ritter O, Brasse H (eds) Proceedings of the 21st Colloquium on Electromagnetic Depth Research. DGG, Potsdam, Germany, pp 339-349
Staudt M (2003) Environmental hydrogeology of Ramotswa. Report by the Environmental Geology Division. Dept of Geological Survey, Lobatse, Botswana

Stephan RM (2009) Transboundary aquifers: managing a vital resource, the UNILC Draft Articles on the Law of Transboundary Aquifers, SC-2008/WS/35, UNESCO, Paris, 24 pp Struckmeier WF, Gilbrich WH, Gun J, Maurer T, Puri S, Richts A, Winter P, Zaepke M (2006) WHYMAP and the world map of transboundary aquifer systems at the scale of $1: 50000000$. Special edition for the 4th World Water Forum, Mexico City, Mexico, March 2006

Tóth J (1963) A theoretical analysis of groundwater flow in small drainage basins. J Geophys Res 68:4795-4812. doi:10.1029/ JZ068i008p02354

Turton A, Godfrey L, Julien F, Hattingh H (2006) Unpacking groundwater governance through the lens of a trialogue: a Southern African case study. Proc. International Symposium on Groundwater Sustainability (ISGWAS), Alicante, Spain, 24-27 January 2006

UNdata (2013) Composition of macro geographical (continental) regions, geographical sub-regions, and selected economic and other groupings, UNdata, UN statistics division. http:// millenniumindicators.un.org/unsd/methods/m49/m49regin.htm. Accessed 16 April 2013

UNEP (2010) Africa water atlas. Division of Early Warning and Assessment, United Nations Environment Programme, Nairobi, Kenya

UNEP/GRID (2004) Population density for Africa in 2000. http:// na.unep.net/siouxfalls/datasets/datalist.php Accessed 16 April 2013

UNESCO (2004) Managing shared aquifer resources in Africa. ISARM-Africa. Proceedings from international Workshop Tripoli, Libya, 2-4 June 2002, IHP-VI, Series on Groundwater no. 8, UNESCO, Paris, $238 \mathrm{pp}$

UNESCO (2008) Managing shared aquifer resources in Africa. Abstracts, Third International Conference, Tripoli, Libya, 25-27 May, 2008, UNESCO, Paris, 82 pp

UNESCO (2010) Transboundary aquifers: challenges and new directions. Abstracts, ISARM 2010 International Conference, Paris, 6-8 December 2010, UNESCO, Paris, 188 pp

UNESCO-IHP (2009) Sharing an invisible water resource for the common good: how to make use of the UN General Assembly Resolution on the Law of Transboundary Aquifers. Seminar convened by UNESCO-IHP, with SIWI, IAH and BGR. Report prepared by Stephan RM, UNESCO-IHP, Paris, 6 pp

UNESCO-IHP (2011) Methodology for the GEF Transboundary Waters Assessment Programme, vol 2: methodology for the assessment of transboundary aquifers. UNEP, Nairobi, Kenya, $\mathrm{vi}+113 \mathrm{pp}$

United Nations (1997) Convention on the Law of Non-Navigational Uses of International Watercourses. G.A. Res. 51/229, UN GAOR, 51st Sess., UN Doc. A/RES/51/229. http://untreaty.un.org/ilc/ texts/instruments/english/conventions/8_3_1997.pdf. Accessed on 16 April 2013

United Nations (2008). Draft Articles on the Law of Transboundary Aquifers, with commentaries. http://untreaty.un.org/ilc/texts/ instruments/english/commentaries/8_5_2008.pdf. Accessed on 16 April 2013

United Nations Economic Commission for Africa (UNECA), African Union (AU), and African Development Bank (AfDB) (2000) The Africa water vision for 2025: equitable and sustainable use of water for socioeconomic development, $28 \mathrm{pp}$. http://www.afdb.org/ fileadmin/uploads/afdb/Documents/Generic-Documents/ african \%20water\%20vision $\% 202025 \% 20$ to $\% 20 \mathrm{be} \% 20$ sent $\% 20$ to \%20wwf5.pdf. Accessed on 16 April 2013

United Nations Economic Commission for Europe (UNECE) (1992) Convention on the protection and use of transboundary watercourses and international lakes. http://www.unece.org/ fileadmin/DAM/env/water/pdf/watercon.pdf. Accessed 16 April 2013

United Nations Economic Commission for Europe (UNECE) (2007) Our waters: joining hands across borders. First assessment of 
transboundary rivers, lakes and groundwaters, UNECE, Geneva, $373 \mathrm{pp}$

United Nations Environment Programme (UNEP) (2000) UNEP/ GRID Sioux Falls. Africa Population Distribution Database. http://na.unep.net/siouxfalls/datasets/datalist.php. Accessed 16 April 2013

United Nations General Assembly (UNGA) (2003) Shared natural resources: first report on outlines, by Mr. C.Yamada, Special Rapporteur. A/CN.4/533/Add.1, 22 pp. http://untreaty.un.org/ilc/ documentation/english/a_cn4_533.pdf. Accessed 16 April 2013

United Nations General Assembly (UNGA) (2012) Resolution adopted by the General Assembly [on the report of the Sixth Committee (A/66/477)] A/RES/66/104. The law of transboundary aquifers. 2 pp http://www.un.org/ga/search/ view_doc.asp?symbol=A/RES/66/104. Accessed 16 April 2013

UN-WATER (2008) Transboundary waters: sharing benefits, sharing responsibilities. Thematic Paper, UN-WATER, 19 pp. www.unwater.org. Accessed May 2013

Vasak S (2008) Inventory of transboundary aquifer and information flow, ISARM-SADC, Gaborone, Botswana

Vasak S, Kukuric N (2006) Groundwater resources and transboundary aquifers of Southern Africa. IGRAC, Delft, The Netherlands, $9 \mathrm{pp}$

Villar PC, Ribeiro WC (2011) The agreement on the Guarani Aquifer: a new paradigm for transboundary groundwater management? Water Int 36(5):646-660

Villholth KG, Vaessen V (2013) Needs assessment to support groundwater management in international basin organisations of Africa. Final
Report, January 2013. BGR and Splash, 84 pp. http://www.splashera.net/downloads/groundwater/Needs_asessment_GW_final.pdf. Accessed 16 April 2013

Villholth KG, Tøttrup C, Stendel M, Maherry A (2013) Integrated mapping of groundwater drought risk in the Southern African Development Community (SADC) region. Hydrogeol J. doi:10.1007/s10040-013-0968-1

Wang L, Dochartaigh BÓ, Macdonald D (2010) A literature review of recharge estimation and groundwater resource assessment in Africa. Internal report IR/10/051, British Geological Survey, Keyworth, UK, 31 pp

Wellfield Consulting, BGS (2011) Groundwater and Drought Management project: regional groundwater monitoring network - transboundary aquifers report, Sep. 2011. www.sadcgwarchive.net. Accessed 16 April 2013

Wolf AT, Natharius JA, Danielson JJ, Ward BS, Pender JK (1999) International river basins of the world. Water Resour Dev 15(4):387-427

World-wide Hydrogeological Mapping and Assessment Programme (WHYMAP) (2006) Groundwater resources of the world: transboundary aquifer systems. BGR and UNESCO. http:// www.whymap.org/whymap/EN/Downloads/Global_maps/ spec_ed_2_map_pdf.pdf?_blob=publicationFile \& v =3. Accessed 16 April 2013

Zeitoun M, Jägerskog A (2011) Addressing power asymmetry: how transboundary water management may serve to reduce poverty. Report no. 29, SIWI, Stockholm, 19 pp 